УДК $550.4,550.46$

\title{
ИССЛЕДОВАНИЕ РАСПРЕДЕЛЕНИЯ ВЫХОДОВ УГЛЕВОДОРОДНЫХ ГАЗОВ В ЗАВИСИМОСТИ ОТ ГЕОЛОГИЧЕСКОГО СТРОЕНИЯ ЮЖНОГО КАСПИЯ ПО ДАННЫМ ГАЗОВОЙ СЪЕМКИ
}

\author{
Полетаев Александр Владимирович', \\ avo1@mail.ru \\ Полетаева Елена Владимировна', \\ yelenapv@mail.ru \\ Национальная Академия Наук Азербайджана, \\ Азербайджан, AZ1000, г. Баку, ул. Ф. Амирова, 9.
}

Актуальность исследования заключается в изучении газов верхней части разреза Южного Каспия, в особенности ее глубоководной части, представляющей значимый практический интерес при поисках и оценках углеводородного потенциала зон газогидратов. Анализ ранее проведенных работ в пределах Южного Каспия показал, что все исследования в основном сконцентрированы в пределах разбуренной зоны Абшеронского, Бакинского и Нижнекуринского нефтегазоносных районов и не охватывают глубоководную зону Южного Каспия.

Цель исследования заключается в изучении распределения интенсивности проявления углеводородных газов по площади, выявлении зон газогенерации, а также проведении работ по определению и анализу путей миграции углеводородов и типов формирования газогидратов в пределах глубоководной зоны Южного Каспия.

Объектом исследования послужили 1282 пробы газа, отобранные в Южном Каспии на месторождениях Шах-дениз, Бахар, Пираллахи, Хали, в глубоководной части Южного Каспия и др., а также данные геолого-геофизических исследований. Использованы данные изучения химического и изотопного состава углеводородных газов Южно-Каспийской впадины по 147 пробам газа, отобранным из нефтегазовых месторождений, 153 пробам из грязевых вулканов, 29 пробам донных осадков и 4 пробам газогидратов. Эти данные позволили более обосновано подойти к анализу генетических вопросов происхождения газов в верхней части разреза.

Методы исследования основаны на интерпретации данных газовой съемки и изучении изотопного и химического состава углеводородных газов Южного Каспия. Наличие точных значений координат, а также данных по структурным картам в координатной сетке позволили сопоставить имеющиеся данные с геологическим строением.

В результате исследования построены карты изменения содержания метана, этана, пропана, бутана, изо-, нормального пентана в пределах верхней части разреза по изучаемым месторождениям. Сопоставлены данные результатов анализа газовой съемки с данными структурных карт и других геолого-геофизических материалов. Установлено, что структура Бахар характеризуется от-

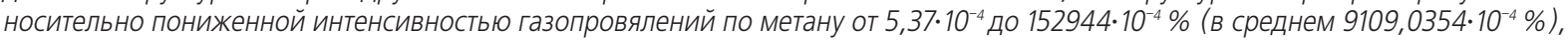
в то время как месторождение Шах-дениз характеризуется максимальными значениями от 4,6200·10-4 до 367840·10-4 \%, в среднем составляя 85572,3·10-4 \%. Небольшие значения интенсивности проявления газа, установленные в зоне структур Пираллахи, Хали, свидетельствуют о незначительном газовом потенциале глубокопогруженных отложений изучаемой зоны. Детально рассмотрены результаты газовой съемки в пределах глубоководной части Южного Каспия и установлено, что для этой зоны характерна газогенерация с преобладанием двух компонентов - метана и этана. Исходя из анализа изменения интенсивности проявления газа по площади и в зависимости от геологических условий установлено, что грязевые вулканы и разломы являются прекрасными путями для миграции углеводородов и отражают геологическую обстановку, генерационный потенциал погруженных отложений Южного Каспия. Установлено, что углеводородные газы в донных осадках и отложениях верхней части разреза Южной части Каспийского моря находятся в тесной зависимости от источников формирования углеводородов, миграции и других процессов, протекающих в глубокопогруженных отложениях, а также в верхней части разреза. Изучены данные химического и изотопного состава газов газогидратов, нефтяных и газовых месторождений Южного Каспия. На базе данных изотопно-геохимических исследований описаны механизмы образования гигантских месторождений нефти Балаханы-Сабунчи-Романы и газоконденсата Шах-дениз, расположенных на одной антиклинальной зоне Абшеронского нефтегазоносного района, а также аномалии, выявленные по данным газовой съемки в пределах изучаемых структур Южного Каспия.

\section{Ключевые слова:}

Газовая съемка, Южный Каспий, разломы, грязевые вулканы, газоносность.

\section{Введение}

Изучению нефтегазоносности Южного Каспия посвящено значительное количество работ [1-12]. В работах $[3-9,11,12]$ авторы детально изучают геохимические параметры и критерии оценки нефтегазоносности основной нефтегазоносной свиты Азербайджана - продуктивной толщи (ПТ) и подстилающих отложений, а также воднорастворенные газы, газы донных осадков и морской воды. Следуют отметить, что углеводородные (УВ) газы Азербайджана главным образом изучались с целью поиска новых нефтяных и газовых месторождений. В связи с чем основной интервал исследова- ний был сконцентрирован на изучении продуктивных горизонтов ПТ и подстилающих отложений, характеризующихся благоприятными условиями для поисков УВ. С продуктивной толщей нижнего плиоцена Азербайджана связаны крупные (с начальными геологическими запасами более 100 млн т н. э) и крупнейшие (с запасами более 500 млн т н. э) месторождения нефти и газа, в которых сосредоточено $87 \%$ доказанных запасов углеводородов и 81 \% добытых с начала разработки нефти и газа. Этот комплекс характеризуется наибольшей удельной плотностью доказанных (разведанных) запасов, перспективных и прогноз- 
ных ресурсов нефти и газа. Область развития этих отложений с установленной нефтегазоносностью, по удельным плотностям потенциальных ресурсов углеводородов, относится к высшей категории перспективных территорий (акваторий). Мощность продуктивной толщи достигает 5000-6000 м в глубоководной впадине Южного Каспия и сокращается на западном борту Южно-Каспийской впадины (ЮКВ), составляя 1500-3000 м в абшеронском переклинальном прогибе, 2000-4000 м в Нижнекуринской впадине и до 5000 м в районе Бакинского архипелага $[4,6,8,11]$. Отложения продуктивной толщи преимущественно выражены дельтовыми образованиями (Палеоволга, Палеокура и др.) и представлены ритмичным чередованием песчано-алевритовых и глинистых пород. Наибольшей песчаностостью разреза (до 70 \%) и высокими емкостными и фильтрационными свойствами коллекторов характеризуется «абшеронская фация» продуктивной толщи, выраженная дельтовыми образованиями Палеоволги, имеющими широкое развитие в ЮКВ. Значительная часть $(88 \%$ ) доказанных (разведанных) запасов нефти и газа в продуктивной толще Азербайджана приурочена к ее «абшеронской фации» $[6,8]$. Ритмичное чередование песчаных коллекторов и глинистых покрышек и благоприятные структурные условия обусловили насыщение углеводородами всего разреза «абшеронской фации» продуктивной толщи, где выделяются до 40 нертегазоносных объектов. C «абшеронской фацией» продуктивной толщи связаны также такие крупные открытия в Азербайджане, как Азери-Чираг-Гюнешли, Шах-дениз, Нефт-Дашлары, Бахар, Биби-Эйбат, Балаханы-Сабунчи-Раманы, Сураханы и др. Более молодые отложения, накопившиеся до абшеронского региояруса, в подавляющем случае состоящие из глинистых осадков, не представляли интереса. Во многих работах эта зона описывается как нерасчлененная толща четвертичных отложений [7]. Верхняя часть разреза главным образом изучалась с целью проведения инженерно-изыскательных работ. Проведены геохимические исследования верхней части разреза на месторождениях Кяпаз, Калмас и др. Углеводородные газы Южного Каспия достаточно хорошо изучены по отдельным зонам и площадям в пределах Абшеронского и Бакинского нефтегазоносных районов. Интерес также представляют работы [1, 2, 6, 13-19], в которых приведены данные и результаты исследования газогеохимии донных осадков Южного Каспия. Несмотря на это, вопросы, связанные с изучением газов верхней части разреза Южного Каспия, в особенности ее глубоководной части, являются актуальной задачей, представляющей значимый практический интерес при поисках и оценках УВ потенциала зон газогидратов.

\section{Методика исследований и фактический материал}

Фактическим материалом для настоящей работы послужили 1282 пробы газа, отобранные в Юж- ном Каспии на месторождениях Шах-дениз, Бахар, Пираллахи, Хали, глубоководной части Южного Каспия и др. (рис. 1), а также данные геологогеофизических исследований. Материалы различных организаций [1-3, 9] проанализированы и приобщены к работе. Наличие точных значений координат, а также данных по структурным картам в координатной сетке позволило сопоставить имеющиеся данные с геологическим строением. Причем создана база данных, которая интегрирована в общую систему анализа геолого-геофизических, термодинамических данных. Основная цель исследований заключается в изучении и выявлении зон максимального выхода газа по площади Южного Каспия. Кроме того, проведены работы по определению и анализу путей миграции УВ и типов формирования газогидратов в пределах глубоководной зоны Южного Каспия. В работе использованы данные изучения химического и изотопного состава УВ газов Южно-Каспийской впадины по 147 пробам газа, отобранным из нефтегазовых месторождений, 153 пробам из грязевых вулканов, 29 пробам донных осадков и 4 пробам газогидратов. Эти данные позволили более обосновано подойти к анализу генетических вопросов происхождения газов в верхней части разреза.

\section{Результаты исследований}

С целью анализа геохимической обстановки среды по месторождениям Шах-дениз, Бахар, Пираллахи, Хали и глубоководной части Южного Каспия построены карты изменения содержания метана, этана, пропана, бутана, изо-, нормального пентана и суммы тяжелых углеводородов в пределах верхней части разреза. Наличие для этой зоны данных газовой съемки позволило установить области повышенной и пониженной газонасыщенности отложений (рис. 2). Структура Бахар характеризуется относительно пониженной интенсивностью газопроявлений по метану от $5,37 \cdot 10^{-4}$ до $152944 \cdot 10^{-4} \%$ (в среднем $9109,0354 \cdot 10^{-4} \%$ ), в то время как месторождение Шах-дениз отличается максимальными значениями от $4,62 \cdot 10^{-4}$ до $367840 \cdot 10^{-4} \%$, в среднем составляя $85572,3 \cdot 10^{-4} \%$. Грязевой вулкан в зоне структуры Бахар имеет канал, установленный [3] в глубокопогруженных отложениях ПТ (рис. 3). Практически вся структура Шах-дениз характеризуется повышенными значениями газоносности.

Месторождение Бахар разрабатывается с 1969 г., а месторождение Шах-дениз только находится в стадии разработки и имеет доказанные запасы газа 1,2 трлн м $^{3}$ и конденсата 240 млн т [20]. Повышенные значения газоносности отложений верхней части разреза позволяют судить о УВ потенциале глубокопогруженных отложений структуры Шах-дениз (рис. 4 [21]). Аналогичные значения интенсивности проявлений газа наблюдаются и на других грязевых вулканах Южного Каспия. Таким образом, можно утверждать, что грязевые вулканы являются прекрасными каналами для 

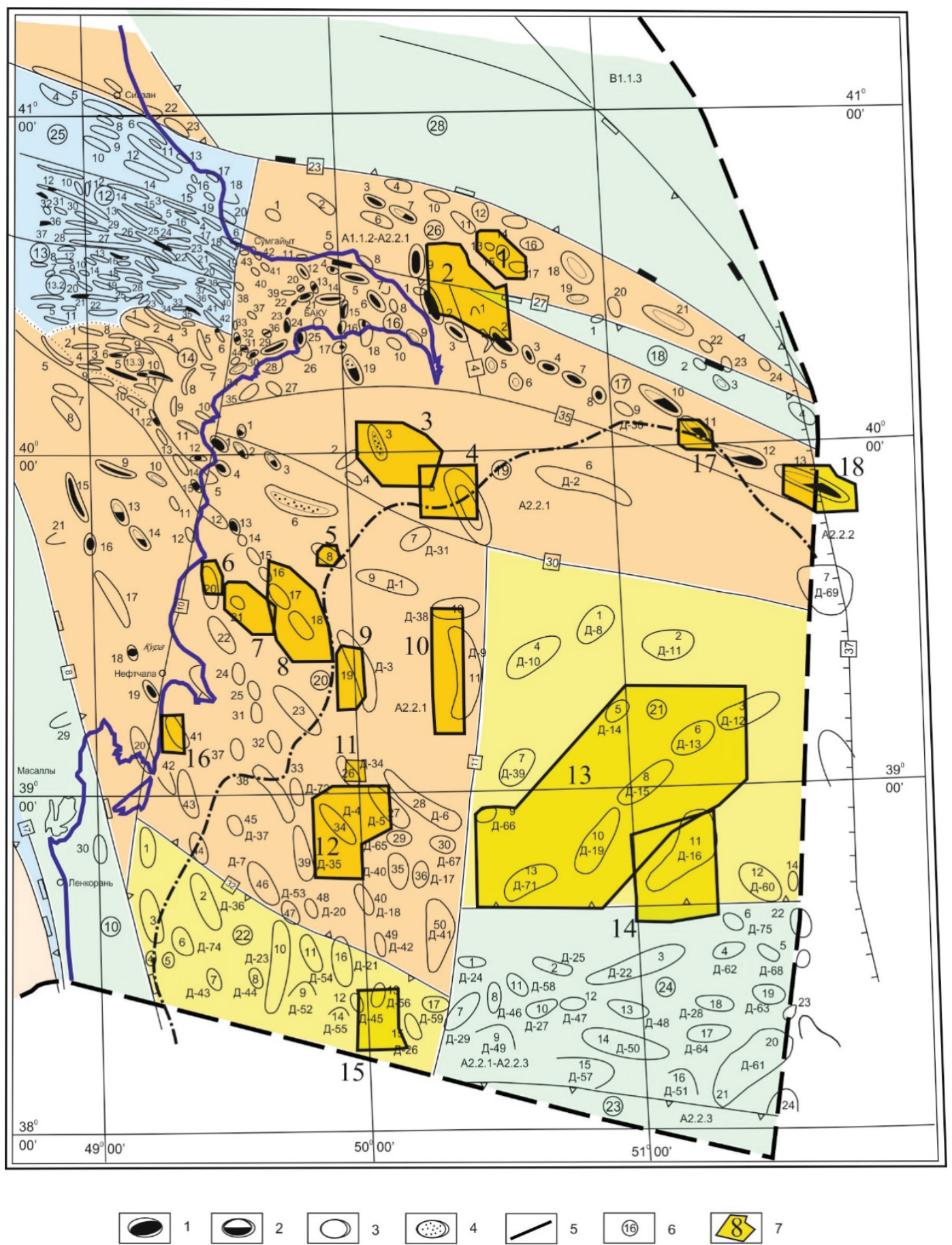

Pис. 1. Карта расположения изучаемых площадей Южного Каспия по данным газовой съемки (в основу положена карта тектонического районирования нефтегазоносных территорий Азербайджана [4]). Условные обозначения:1 - нефтяные месторождения; 2 - нефтегазовые месторождения; 3 - газовые месторождения; 4 - нефтегазоконденсатные месторождения; 5 - берег моря; 6 - номер района; 7- зоны, покрытые газовой съемкой

Puc. 1. Map of location of the studied areas of the South Caspian according to the data of the gas survey (the map is based on the map of tectonic zoning of oil and gas bearing territories of Azerbaijan [4]). Legend: 1 are the oil fields; 2 are the oil-gas fields; 3 are the gas fields; 4 are the oil and gas condensate fields; 5 is the sea shore; 6 is the number of a region; 7 are the zones covered with gas survey

миграции УВ. Большое влияние на миграцию газа из одного горизонта в другой оказывает, по-видимому, пластовое давление газовых месторождений.
Для каждого месторождения существует свой предел пластового давления, при котором миграция УВ перестает быть интенсивной. Этот предел зависит от многих причин, но прежде всего - от да- 


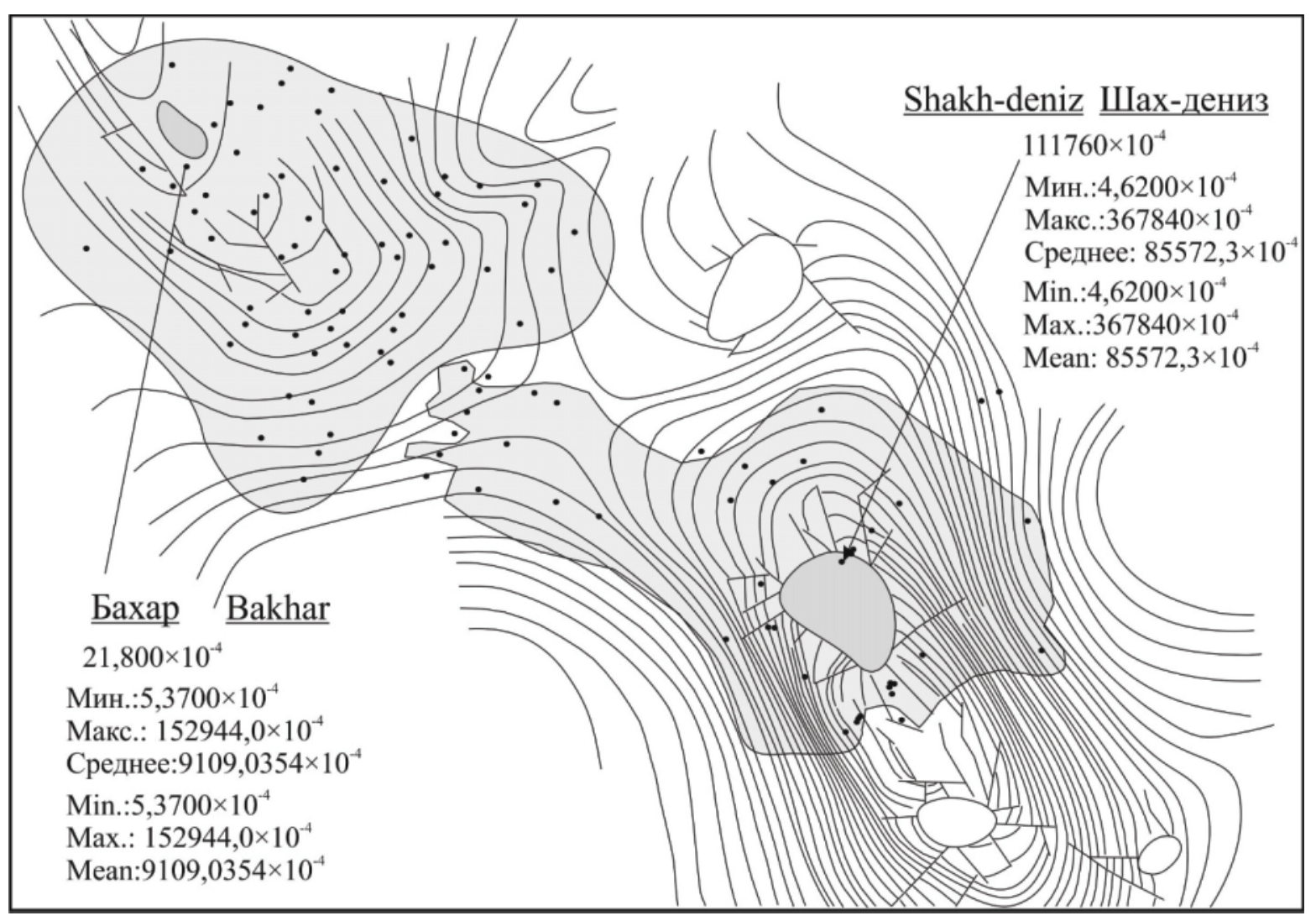

Рис. 2. Карта интенсивности проявлений газа (метан) по площади Шах-дениз-Бахар

Fig. 2. Map of gas (methane) manifestations intensity by Shakh-deniz-Bakhar area

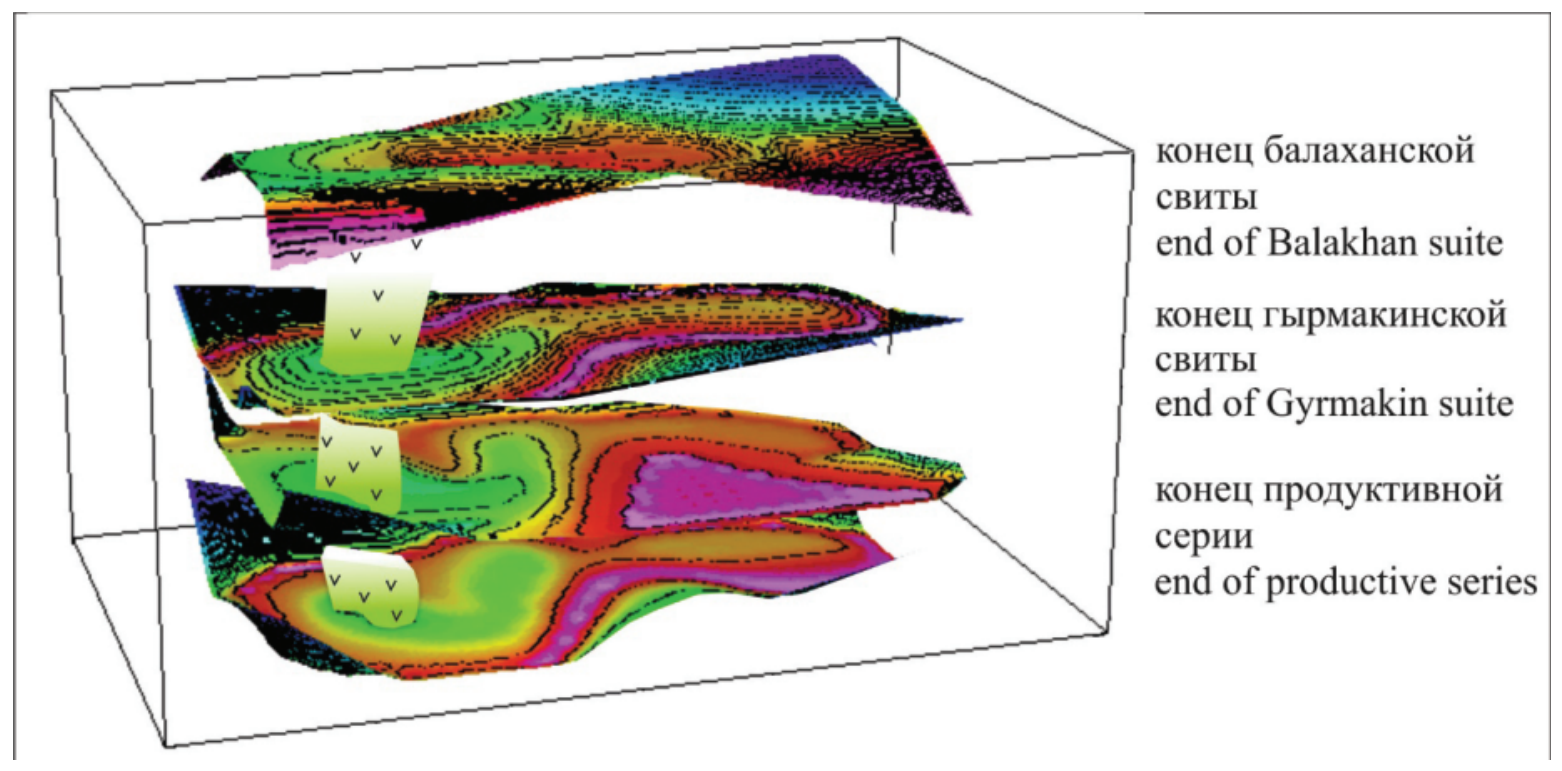

Рис. 3. Модель грязевого вулкана Бахар

Fig. 3. Model of Bakhar mud volcano

вления в основном продуктивном горизонте, от физических и геологических особенностей месторождения, качества и режима эксплуатации действующих скважин и интенсивности разработки месторождения в целом [22]. Анализ данных по глубоководной части Южного Каспия указывает на высо- кие значения газоносности зон и, следовательно, на высокие объемы перетока газа в верхнюю часть разреза (ВЧР).

Большой интерес представляет зона ПиралахиХали, на поверхности которой последовательно обнажаются четвертичные отложения [1]. Страти- 


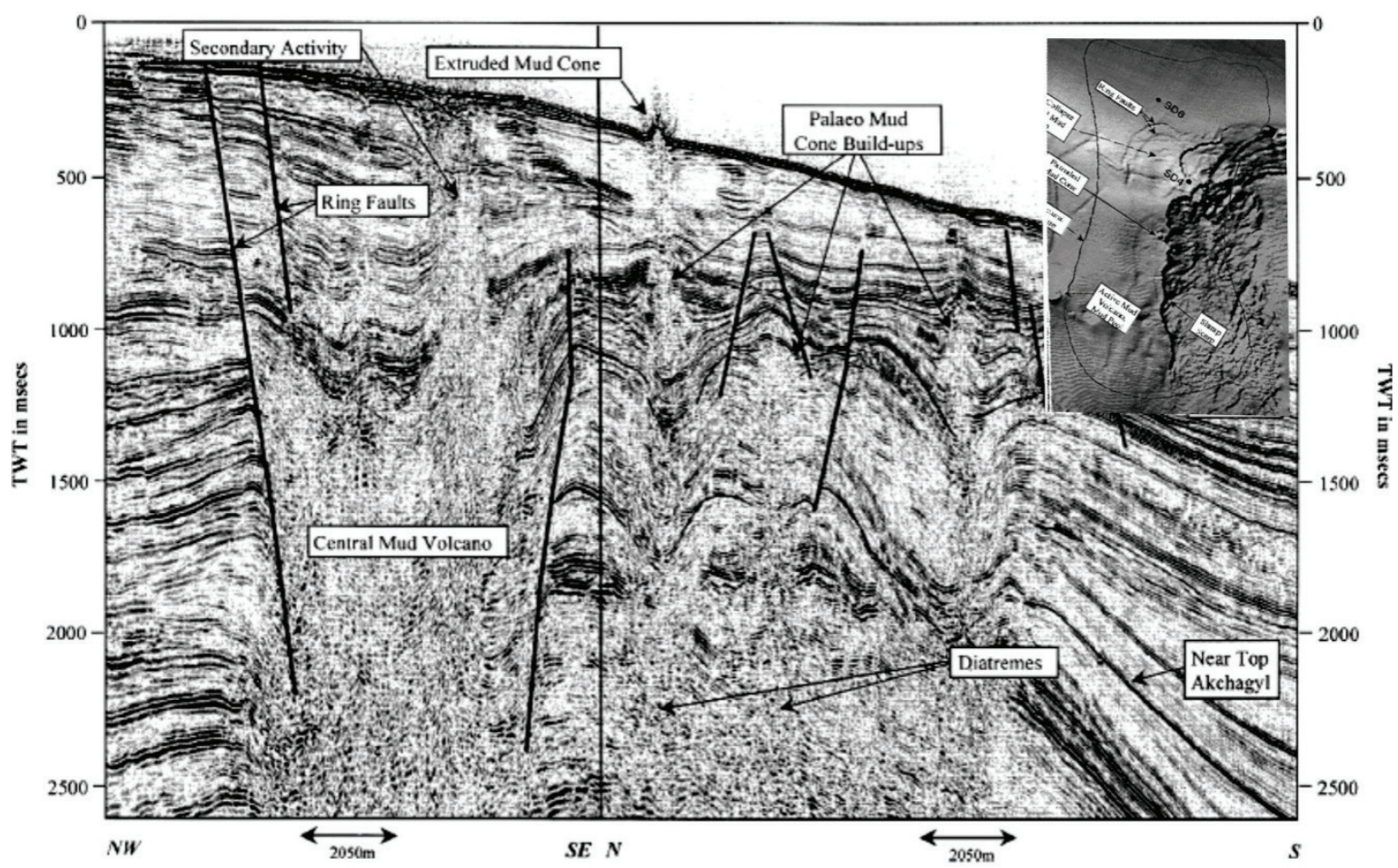

Pис. 4. Грязевые вулканы на структуре Шах-дениз [21]

Fig. 4. Mud volcanoes on Shakh deniz structure [21]

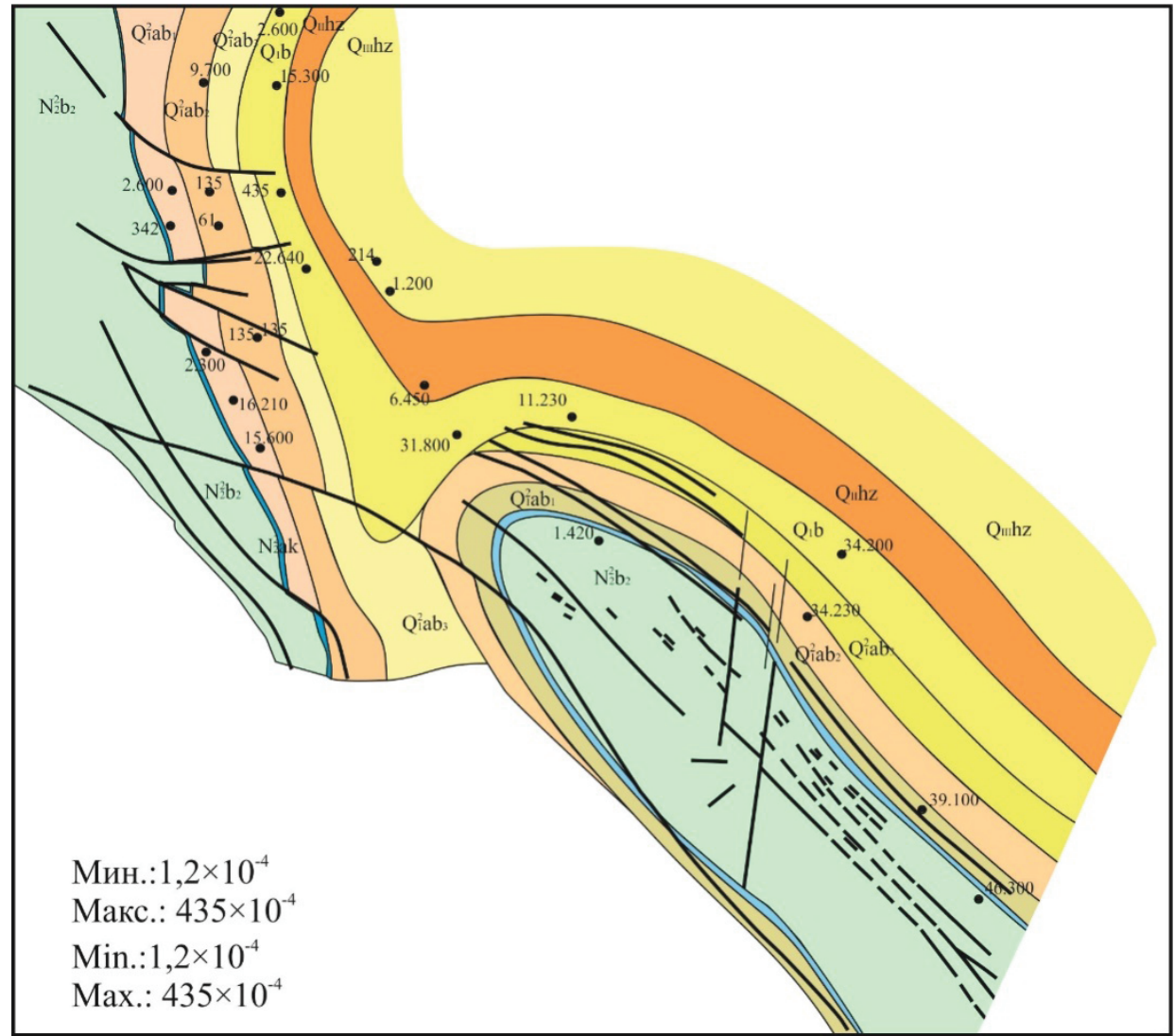

Рис. 5. Интенсивность проявления газа (метан) на структуре Пирллахи-Хали (Геологическая карта [1])

Fig. 5. Intensity of gas (methane) show on Pirlakhi-Khali structure (geological map [1]) 
графически они представлены отложениями хазарского, бакинского горизонта и др. (рис. 5). Следует отметить, что здесь наблюдаются пониженные значения интенсивности проявления метана, этана, пропана и др., причем намного ниже, чем на структуре Шах-дениз.

Небольшие значения, установленные в зоне структур Пираллахи, Хали, указывают на незначительный газовый потенциал глубокопогруженных отложений изучаемой зоны.

Следует отметить, что в зонах разломов (рис. 5) устанавливаются наиболее повышенные значения концентрации метана, которые несоизмеримы с данными, зафиксированными на структуре Шахдениз и других структурах глубоководной части Южного Каспия.

Детально рассмотрены результаты газовой съемки в пределах глубоководной части Южного Каспия на структурах Д-5, Д-4, а также на северной части структур Д-18, Д-40, Машал (Д-38) и Зафар (Д-9) и др. Причем газовая съемка покрывала зону расположения грязевого вулкана на структуре Машал. Кольцевые аномалии в северной части структуры Нахчыван (Д-3) установлены в зоне грязевого вулкана. Проанализированы также данные по газовой съемке структур Д-71, Араз (Д-19), Алов (Д-15), Шерг (Д-13), Д-12 и прилагающих к ним зонам, за исключением структур Д-75 и Д-16.

Как видно из распределения данных по площади и сопоставления их с геологической картой, максимальные концентрации соответствуют структурным поднятиям, а также зонам разломов, в сопредельных же частях структур концентрации уменьшаются. На структуре Д-26 установлены высокие концентрациин-пентана $\left(10472 \cdot 10^{-4} \%\right)$. Газовая съемка проведена в зоне расположения грязевого вулкана. Более низкие концентрации н-пентана $\left(280,5 \cdot 10^{-4} \%\right)$ установлены в южной части структуры Д-56. В целом в этой зоне наблюдаются различные значения концентраций метана.

Высокое содержание суммы тяжелых углеводородов в пределах верхней части разреза показывает, что УВ газы являются как мигрированными из более глубокопогруженных отложений, соответствующих термокаталитической зоне формирования, так и происходящими из диагенетической зоны.

На карте, построенной по данным интенсивности проявления метана (рис. 6), в пределах глубоководной части Южного Каспия можно выделить три основные зоны, которые сконцентрированы в южной и северо-западной части карты. Высокие значения интенсивности проявления метана установлены на структурах Д-12, Д-13 (Шерг), Д-15 (Алов) и др. Проявляется четкая взаимосвязь между выходами газа и разломами, выделенными в этой зоне. В областях, прилегающих к зонам разломов, интенсивность проявления метана более высокая по сравнению с другими областями. Здесь отмечаются значения интенсивности проявления метана $179520 \cdot 10^{-4} \%$, на фоне более пониженных аномалий $6160 \cdot 10^{-4} \%$. Следует отметить, что наблюдается определенная взаимосвязь между выходами метана, этана и других компонентов газа. Целая серия грязевых вулканов установлена около структуры Д-26 в Южной части Каспия. Здесь интенсивность проявления метана составляет $58080 \cdot 10^{-4} \%$, а этана $58080 \cdot 10^{-4} \%$. Высокая интенсивность проявления газа также наблюдается на структуре Зафар. Здесь значения по метану составляют $202400 \cdot 10^{-4} \%$, а по этану $-900 \cdot 10^{-4} \%$. На поблизости расположенной структуре Машал (Д-38) значения интенсивности проявленияснижаются по метану $116160 \cdot 10^{-4} \%$, по этану $2520 \cdot 10^{-4} \%$. Выходы тяжелых компонентов гомолога метана установлены для ряда структур: Чираг-Азери, Машал, Зафар, Нахчыван, Д-12, Д-13 (Шерг), Д-71, Д-75 и Д-26. Высокие значения интенсивности проявления тяжелых компонентов могут свидетельствовать о том, что эти зоны благоприятны для поисков нефтяных залежей. Значения интенсивности проявления выхода нор-пентана на структуре Зафар составляет $2281,4 \cdot 10^{-4} \%$, в то время как на структуре Машал - 377,74:10-4 \% . Большой разброс значений наблюдается и в зоне структур Д-12, Шерг, Алов и Араз. Здесь установлены значения $97,92 \cdot 10^{-4}, 10771,2 \cdot 10^{-4}, 9,900 \cdot 10^{-4} \%$ и т. д. Высокие значения концентраций установлены в зонах разломов и грязевых вулканов и отражают общий генерационных потенциал глубокопогруженных залежей нефти и газа. Следовательно, на поверхности фиксируются высокие значения концентраций метана, тяжелых углеводородов, что и приводит к формированию скоплений газов с преимущественным содержанием тяжелых углеводородов в верхней части разреза. Этим и обуславливается присутствие тяжелых углеводородов в ранее установленных газогидратах $[6,13,14,16,17]$.

На карте (рис. 7), построенной для суммы тяжелых углеводородов (сумма ТУ), можно выделить аномалии различных порядков. Выделяются обширные области максимумов суммы ТУ. В Cеверной части Южного Каспия в области АбшероноПрибалханского порога сгущения изолиний наблюдаются в пределах месторождения Азери. Установлено, что между месторождениями Азери и Кяпяз выделяется максимум со значением интенсивности $1800 \cdot 10^{-4} \%$. Наибольшее значение $53168 \cdot 10^{-4} \%$ отмечается на месторождении Азери. От месторождения Азери сгущения изолиний расходятся как в северном, так и южном направлениях. В южной части Каспия в области Бакинского архипелага на месторождении Машал (Д-38) отмечается значительный максимум интенсивности проявления суммы ТУ равный 9032,82:10-4\% . На карте изолинии расходятся от этого максимума в северную сторону. Выделяются аномалии овальной формы со сгущением изолиний в южной части. От центральной части месторождения Машал (D-38) в направлении месторождения Зафар (Д-9) наблюдается уменьшение значений суммы ТУ $\left(9032,82 \cdot 10^{-4}, 2904,8 \cdot 10^{-4}, 177,78 \cdot 10^{-4}, 20,95 \cdot 10^{-4}\right.$, 


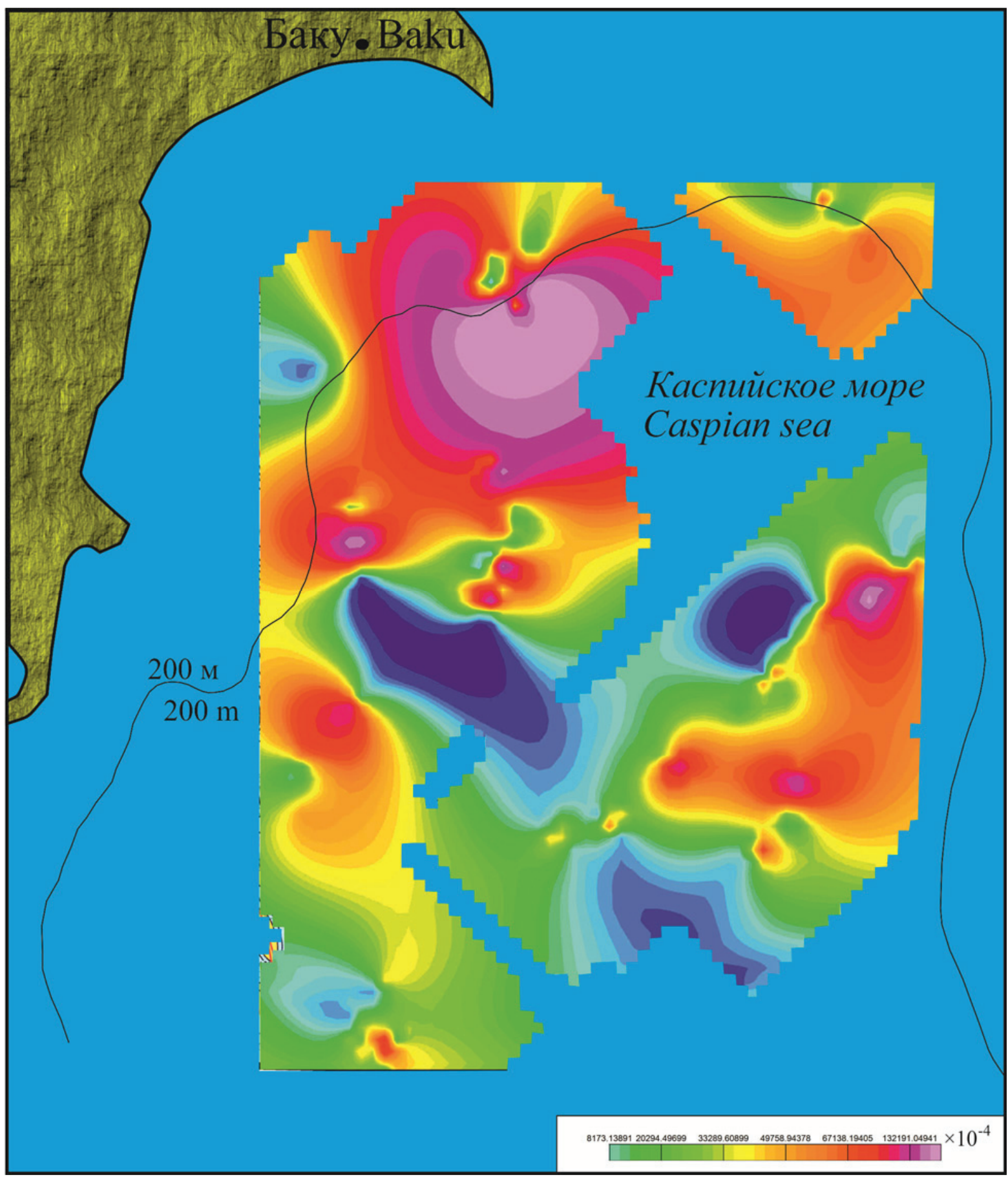

Рис. 6. Распределение интенсивности проявления газа (метан) по площади в глубоководной части Южного Каспия

Fig. 6. Area distribution of gas show (methane) intensity in the deep-water part of the South Caspian

$10,32 \cdot 10^{-4}$ и $\left.0,53 \cdot 10^{-4}\right)$. Низкие значения суммы ТУ выявляются между месторождениями Машал (Д-38) и Зафар (Д-9), а также в северной части месторождения Зафар (Д-9). К центральной части месторождения Зафар (Д-9) значения суммы ТУ повышаются. В пределах месторождения Зафар (Д-9) отмечаются два локальных максимума, меридионально ориентированные вдоль этого месторождения. В центральной части месторождения просле- живается более интенсивные проявления. Максимальное значение суммы ТУ здесь составляет $10982,400 \cdot 10^{-4}$. По обе стороны от максимума как в северо-западную, так и юго-восточную сторону значения суммы ТУ уменьшаются. В направлении северо-западной части наблюдаются наиболее пониженные значения $-5,17 \cdot 10^{-4} \%$, а в юго-восточной части немного повышенные $-515,100 \cdot 10^{-4} \%$. Южнее с этим максимумом кулисообразно сочле- 
няются менее интенсивные максимумы, значения суммы ТУ которых составляют $562,60 \cdot 10^{-4}$, $279,30 \cdot 10^{-4}, 12,46 \cdot 10^{-4}$ и $0,5160 \cdot 10^{-4} \%$, соответственно.

Для более полного представления о ВЧР все данные отсортированы по минимальным, максимальным и средним значениям. Содержание метана для зоны 13 (рис. 1) изменяется от минимального $13,2 \cdot 10^{-4}$ до максимального значения $290400 \cdot 10^{-4}$, в среднем составляя $52138,1763 \cdot 10^{-4}$. Арифметическая сумма составляет $4066777,75 \cdot 10^{-4}$. Таким способом проанализированы и другие площади. Одним из важных диагностических признаков является определение арифметической суммы, которая позволяет оценить объемы выхода газа для различных месторождений. Если рассматривать зоны по данным, полученным по арифметической сумме (табл. 1), то максимальные выходы метана соответствуют глубоководной части Южного Каспия зоне 13. Далее по мере убывания содержания метана зоны располагаются следующем порядке: 4,10 , 14 и 9 . Заключает этот список зона 16 (месторождение Нефтчала). Если рассматривать арифметическую сумму по этану, то максимальные концентрации наблюдаются в зонах $13,6,15$ и 10. Самые минимальные значения соответствуют зоне 16 (месторождение Нефтчала). По данным н-бутана максимальные значения соответствуют зоне 17 . Большой интерес представляет глубоководная часть Каспийского моря, которая имеет максимальные значения по метану и этану на порядок выше, чем сопредельные месторождения.

Как видно из рис. 6,7 , для месторождения Бендован (зона 6) наблюдаются высокие значения концентрации метана и его гомологов, в то время как в глубоководной зоне Южного Каспия метан и этан являются основным компонентами. Высокие значения суммы тяжёлых углеводородов установлены только в ряде зон: 13,17 , и 15 . Для других зон интенсивность проявления гомологов метана минимальна. Таким образом можно ожидать, что газогидраты, в состав которых входят гомологи метана, будут установлены в зонах $13,17,15$ и 10 . Для других зон наиболее вероятно наличие газогидратов, содержащих в своей структуре в основном метан. Следует отметить, что по данным бурения на структуре Бяндован в скважинах 25 и 26 продуктивные блоки не установлены. В зоне, ближайшей к структуре Бяндован, наблюдается целая серия месторождений, таких как Гарасу, Санги-мугань, Чигил-дениз, Янан-Тава. Гарасу и Санги-мугань, которые входят в структурную зону Хамамдаг-денизГарасу-Саги-Мугань-Аран-дениз-Дашлы-Сабаил.

Эта зона располагается в центральной части Бакинского архипелага. Основным нефтяным горизонтом является VII горизонт продуктивной толщи. Нефть была получена на структуре Гарасу с VII горизонта винтервале глубин от 4861 до 4855 из скважины 25 с дебитом 200 т в день, а газа - 100 м $^{3}$ (с общими запасами нефти 30 млн т на период 1993 г.). На площади Саги-Мугань запасы нефти не установлены. Исходя из анализа фактического материала на структуре Аран-дениз были выявлены газы от метана до бутана включительно с преобладанием метана. Однако наличие более тяжёлых гомологов не отмечается. На структуре Чигиль-дениз также наблюдаются значительные выходы газа (рис. 1, зона 7) и присутствие значительных концентраций гомологов метана до пентана включительно. Повышенные концентрации мета-

Таблица 1. Интенсивность проявления выходов УВ газов по площадям Южного Каспия (арифметическая сумма)

Table 1. Intensity of HC gases emissions by the areas of the Southern Caspian (arithmetic sum)

\begin{tabular}{|c|c|c|c|c|c|c|c|c|}
\hline $\mathrm{CH} 4$ & $\mathrm{C} 2 \mathrm{H} 6$ & $\mathrm{C} 3 \mathrm{H} 8$ & $\mathrm{C} 4 \mathrm{H} 8$ & $\mathrm{iC} 4 \mathrm{H} 10$ & $\mathrm{nC} 4 \mathrm{H} 10$ & $\mathrm{iC} 5 \mathrm{H} 12$ & $\mathrm{nC} 5 \mathrm{H} 12$ & Площадь исследования/Study area \\
\hline \multicolumn{8}{|c|}{$\times 10^{-4} \%$} & \\
\hline 63132,88 & 203,86 & 67,7239 & - & 28,7577 & 57,4078 & - & 4,073 & 1 \\
\hline 5094,41 & 23,808 & 12,4362 & - & 2,357 & 15,626 & - & 3,217 & 2 \\
\hline 1493881,8 & 0,16 & 7,129 & - & - & 10,201 & - & - & 3 \\
\hline 2909458,2 & 286,345 & 7,85 & - & - & - & - & - & 4 \\
\hline 1709,18 & 5,54 & 0,2 & - & 0,64 & - & - & - & 5 \\
\hline 12706,35 & 43238,444 & 83,613 & - & 25,787 & 42778,7116 & - & 0,397 & 6 \\
\hline 5457,365 & 14,7431 & 2,2575 & - & 1,1457 & 0,6204 & - & 0,0764 & 7 \\
\hline 78897,22 & 6,539 & 14,244 & 22,914 & 11,573 & 20,489 & - & - & 8 \\
\hline 1619316,38 & 1140,29 & 100,1 & - & 42,72 & 24,24 & 35,36 & 21,42 & 9 \\
\hline 2366362,46 & 14606,885 & 7853,95 & - & 27,92 & 57,68 & 480,55 & 2773,38 & 10 \\
\hline 36960 & 306 & 11,5 & - & 48 & 1,2 & 43,01 & 29,92 & 11 \\
\hline 963571,4 & 5561,03 & 1503,25 & - & 659,71 & 178,72 & 8415 & 1012,81 & 12 \\
\hline 4066777,75 & \begin{tabular}{|l|l|}
117500,99 \\
\end{tabular} & 135682,15 & 6525,28 & 154489,39 & 14952,25 & - & 17372,96 & 13 \\
\hline 1747314,91 & 6593,33 & 5203,15 & 89,92 & 3927,71 & 106,08 & 1859,8 & - & 14 \\
\hline 510891,7 & 40918,55 & 1502,7 & - & 5660,68 & 242,4 & - & 10779,7 & 15 \\
\hline 7,4367 & 0,0128 & 0,0152 & - & 0,0075 & 0,0107 & - & - & 16 \\
\hline 717366,84 & 9055,71 & 18400,15 & 373,6 & 19667,77 & 9133,08 & 18587,8 & 38790,6 & 17 \\
\hline 2741,78 & 676,5 & 446,7 & 564 & 76,5 & - & - & - & 18 \\
\hline 14939728,82 & 195974,67 & 170265 & 6988,8 & 184526,22 & 24696,45 & 47260,64 & 70780,79 & $\begin{array}{c}\text { Глубоководная часть Каспийского моря } \\
\text { (от изобаты - } 200 \text { м) } \\
\text { Deep-water part of the Caspian Sea } \\
\text { (from the isobaths }-200 \mathrm{~m} \text { ) }\end{array}$ \\
\hline
\end{tabular}




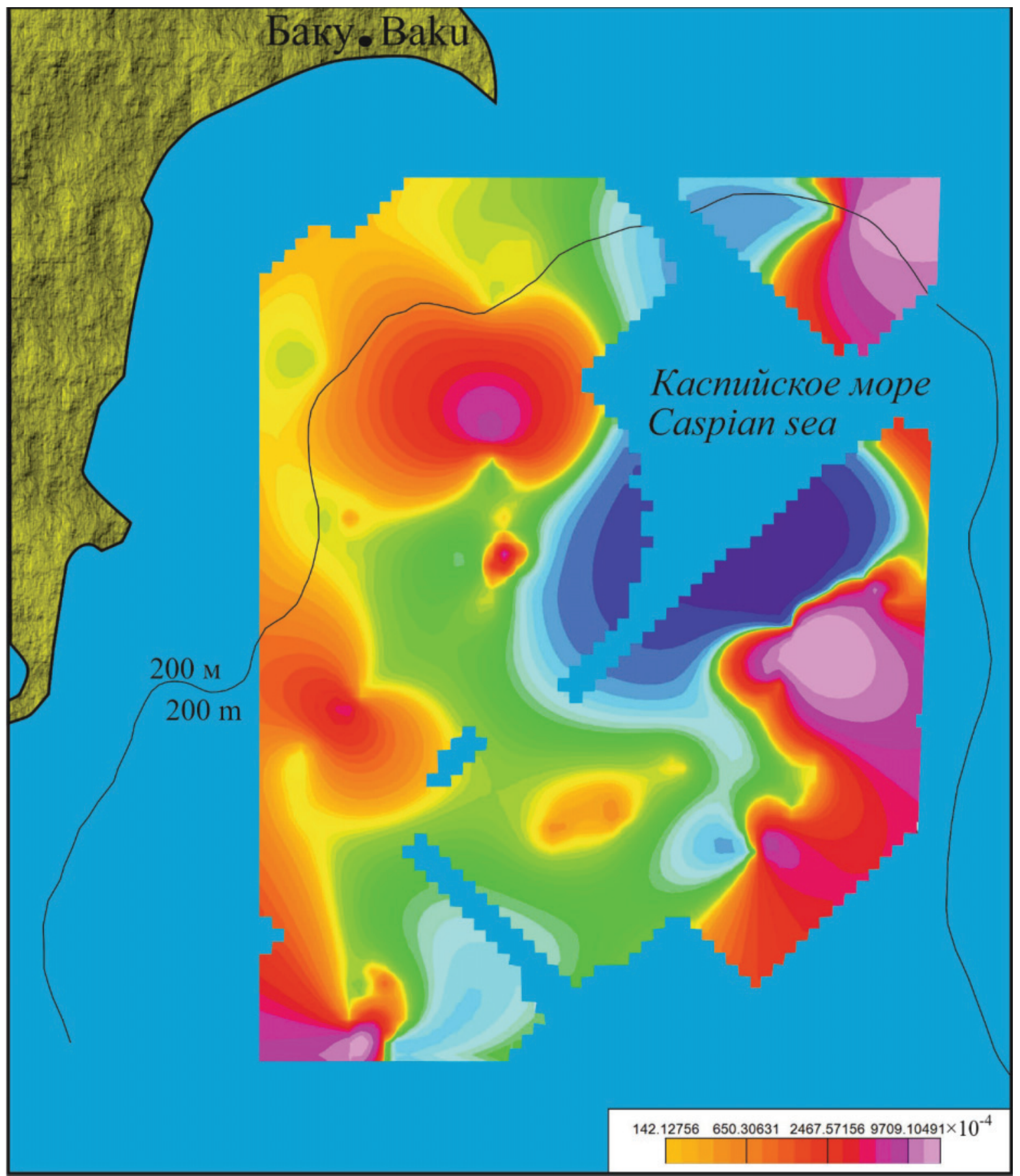

Рис. 7. Распределение интенсивности проявления газа (суммы тяжелых углеводородов) по площади в глубоководной части Южного Каспия

Fig. 7. Area distribution of gas show (the sum of heavy hydrocarbons) intensity in the deep-water part of the South Caspian

на и более тяжелых гомологов наблюдаются на структуре Нефтечала-дениз. По данным бурения на многих структурах выделены газопроявления, в то время как присутствие нефти установлено только в верхней части разреза на структуре Дашлы. При анализе геолого-геофизических, геохимических данных можно проследить аналогичные аномалии, выделенные при изучении зон газогидратов в разных регионах мира [23-37].
В табл. 2 приведены изотопные составы углерода и водорода метана и его гомологов, а также кислорода углекислого газа в газах газоконденсатных залежей, газовых шапок, растворенных в нефтях газов, грязевых вулканов и донных осадков. Из табл. 2 следует, что изотопные составы углерода газов нефтяных, газовых и газоконденсатных залежей и грязевых вулканов мало отличаются друг от друга, что указывает на общую их ге- 
нетическую природу. Наряду с этим отмечается последовательное облегчение изотопа углерода метана от газов газоконденсатных месторождений к газам донных осадков. Изотопный состав углерода газов донных осадков отличается от газов нефтегазовых месторождений, газоконденсатных месторождений и грязевых вулканов облегченным изотопом углерода метана. Изотопы углерода газов кристаллогидратов близки по изотопному составу к газам грязевых вулканов. Изучение химического и изотопного состава газов проведено на скоплениях газогидратов Боздаг, Элм по 4 пробам (табл. 2). Значения изотопа углерода метана в зависимости от содержания изотопа водорода метана в газах кристаллогидратов колеблются от $-55,7$ до $-44,8 \%$, что позволяет отнести изучаемые газы к зоне главной фазы газообразования и охарактеризовать их как миграционные. Газы донных осадков Каспийского моря приурочиваются к биохимической зоне. В разрезе мезо-кайнозойской осадочной толщи выделены газы биогенного, диагенетического и термокаталитического генезиса, причем последние относятся к различным фазам генерации. Таким образом, вверхней части разреза обнаружены газы с широким диапазоном изменения химического состава газа: от биогенных газов, образованных в результате биохимических процессов в современных осадках, до миграционных, смешенных и термокаталитических газов.

Углеводородные газы в донных осадках, а также в отложениях верхней части разреза Южной части Каспийского моря находятся в тесной зависимости от источников формирования УВ, миграции и других процессов, протекающих в верхней части разреза. В связи с этим в работе также рассмотрено изменение изотопного состава УВ-газов в
Таблица 2. Изменение изотопного состава УВ газа в зависимости от формы его проявления

Table 2. Change of isotope composition of HC gas depending on the form of their manifestation

\begin{tabular}{|c|c|c|c|c|c|c|}
\hline \multirow{2}{*}{$\begin{array}{c}\text { Форма проявления } \\
\text { газов } \\
\text { Form of gas show }\end{array}$} & \multicolumn{6}{|c|}{$\begin{array}{l}\text { Изотопный состав компонентов газа, \% } \\
\text { Isotopic composition of gas components, \% }\end{array}$} \\
\hline & $C_{1}$ & $\mathrm{DCH}_{4}$ & $\mathrm{C}_{2}$ & $\mathrm{C}_{3}$ & $C_{4}$ & $\mathrm{CO}_{2}-\mathrm{O}$ \\
\hline \multicolumn{7}{|c|}{ Месторождения/Fields } \\
\hline $\begin{array}{l}\text { Газоконденсатные } \\
\text { Gas condensate }\end{array}$ & $-42,8$ & $-193,7$ & $-28,2$ & $\mid-25,4$ & $\mid-25,7$ & $-7,3$ \\
\hline Газовые/Gas & $-43,0$ & $-233,0$ & $|-27,7|$ & $-26,0$ & - & $-5,0$ \\
\hline $\begin{array}{l}\text { Нефтяные залежи } \\
\text { с газовой шапкой } \\
\text { Oil fields with gascap }\end{array}$ & $|-44,9|$ & $-216,9$ & $-29,2$ & $-25,0$ & $-25,2$ & $-2,8$ \\
\hline $\begin{array}{l}\text { Нефтяные месторож- } \\
\text { дения с газом, ра-- } \\
\text { створенным в нефти } \\
\text { Oil fields with gas } \\
\text { dissolved in oil }\end{array}$ & $\mid-45,9$ & $-202,0$ & $|-29,7|$ & $-23,7$ & $\mid-26,1$ & $-2,4$ \\
\hline $\begin{array}{l}\text { Грязевые вулканы } \\
\text { Mud volcanoes }\end{array}$ & $-46,2$ & $-199,5$ & $-27,4$ & $-25,9$ & - & - \\
\hline $\begin{array}{l}\text { Kристаллогидраты } \\
\text { Crystalhydrates }\end{array}$ & $-50,2$ & - & $-26,5 \mid$ & -15 & $\mid-25,9$ & - \\
\hline $\begin{array}{l}\text { Донные осадки } \\
\text { Bottomsediments }\end{array}$ & $-79,9$ & - & - & - & - & - \\
\hline
\end{tabular}

зависимости от стратиграфического возраста вмещающих отложений. Установлено, что в разрезе абшеронского и акчагыльского ярусов и продуктивной толщи (ПТ) со стратиграфической глубиной происходит утяжеление изотопов углерода не только метана, но и его гомологов (рис. 8, табл. 3). Изучение изменения изотопного состава углеводородных газов в зависимости от стратиграфического возраста вмещающих отложений позволило выделить две фазы формирования УВ в пределах осадочного комплекса, в связи с чем наблюдается ре-

Таблица 3. Изменение изотопного состава УВ газов в зависимости от стратиграфического возраста вмещающих пород

Table 3. Change in isotope composition of HC, depending on stratigraphic age of enclosing rocks

\begin{tabular}{|c|c|c|c|c|c|c|c|c|c|c|c|}
\hline \multirow{3}{*}{ 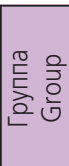 } & \multirow{3}{*}{ 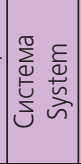 } & \multirow{3}{*}{$\begin{array}{l}\text { Отдел } \\
\text { Series }\end{array}$} & \multirow{3}{*}{$\begin{array}{l}\text { Подотдел } \\
\text { Sub-series }\end{array}$} & \multirow{3}{*}{$\begin{array}{l}\text { Ярус, свита, горизонт, отложения } \\
\text { Stage, suite, horizon, deposits }\end{array}$} & \multicolumn{7}{|c|}{$\begin{array}{l}\text { Изотопный состав компонентов газа, \%о } \\
\text { Isotopic composition of gas components, \%o }\end{array}$} \\
\hline & & & & & $\mathrm{C} 1$ & $\mathrm{C} 1$ & $\mathrm{C} 2$ & $\mathrm{C3}$ & C4 & $\mathrm{CO} 2$ & $\mathrm{CO} 2$ \\
\hline & & & & & $\mathrm{d} 13 \mathrm{C}$ & $\mathrm{dД}$ & $\mathrm{d} 13 \mathrm{C}$ & $d 13 c$ & $d 13 c$ & $d 13 C$ & $\mathrm{~d} 180$ \\
\hline \multirow{12}{*}{$\underline{v}$} & O & - & - & Абшеронский/Absheron & $-51,1$ & - & -32 & $-27,5$ & - & - & - \\
\hline & \multirow{9}{*}{ 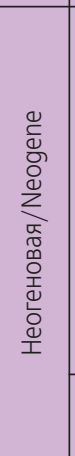 } & \multirow{7}{*}{$\begin{array}{l}\text { Плиоценовый } \\
\text { Pliocene }\end{array}$} & \multirow{7}{*}{ Нижний/Lower } & Сураханская/Surakhan & $-48,33$ & -216 & $-29,6$ & $-24,8$ & $-27,7$ & -2 & $-6,5$ \\
\hline & & & & Сабунчинская/Sabunchi & $-54,9$ & - & \begin{tabular}{|l|}
$-32,2$ \\
\end{tabular} & $-29,2$ & - & - & - \\
\hline & & & & Балаханская/Balakhan & $-41,69$ & -203 & $-28,2$ & -24 & $-24,9$ & 0 & $-5,2$ \\
\hline & & & & $\begin{array}{l}\text { Надкирмакинская свита } \\
\text { Over-Kirmaki suite }\end{array}$ & $-45,6$ & - & -28 & $-24,9$ & - & - & - \\
\hline & & & & Кирмакинская свита/Kirmakisuite & $-43,3$ & -212 & \begin{tabular}{|l|}
$-27,3$ \\
\end{tabular} & $-21,7$ & \begin{tabular}{|l|}
$-25,7$ \\
\end{tabular} & 12 & $-1,4$ \\
\hline & & & & $\begin{array}{l}\text { Подкирмакинская свита } \\
\text { Sub-Kirmakisuite }\end{array}$ & $-43,59$ & -199 & $-28,4$ & -23 & $-25,2$ & 3 & $-2,2$ \\
\hline & & & & Калинская свита/Kalinesuite & $-40,16$ & -243 & $-23,2$ & $-21,9$ & $-19,8$ & 13,8 & -2 \\
\hline & & \multirow{2}{*}{$\begin{array}{c}\text { Миоценовый } \\
\text { Miocene }\end{array}$} & Средний/Middle & Чокракский/Chokrak & $-50,49$ & -207 & $-34,6$ & -30 & $-28,3$ & $-3,3$ & $-2,8$ \\
\hline & & & Нижний/Lower & \multirow[b]{2}{*}{ Майкопская серия/Maycop suite } & \multirow[b]{2}{*}{$-49,25$} & \multirow[b]{2}{*}{-210} & \multirow[b]{2}{*}{$-35,8$} & \multirow[b]{2}{*}{$-30,7$} & \multirow[b]{2}{*}{$-29,3$} & \multirow[b]{2}{*}{6,5} & \multirow[b]{2}{*}{$-1,9$} \\
\hline & 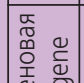 & $\begin{array}{c}\text { Олигоценовый } \\
\text { Oligocene }\end{array}$ & - & & & & & & & & \\
\hline & $\mid$ & $\begin{array}{l}\text { Эоценовый } \\
\text { Eocene }\end{array}$ & - & Коунские отложения/Conician deposits & $-42,6$ & -196 & $-28,4$ & $-27,5$ & $-28,4$ & 11,4 & 2,1 \\
\hline
\end{tabular}




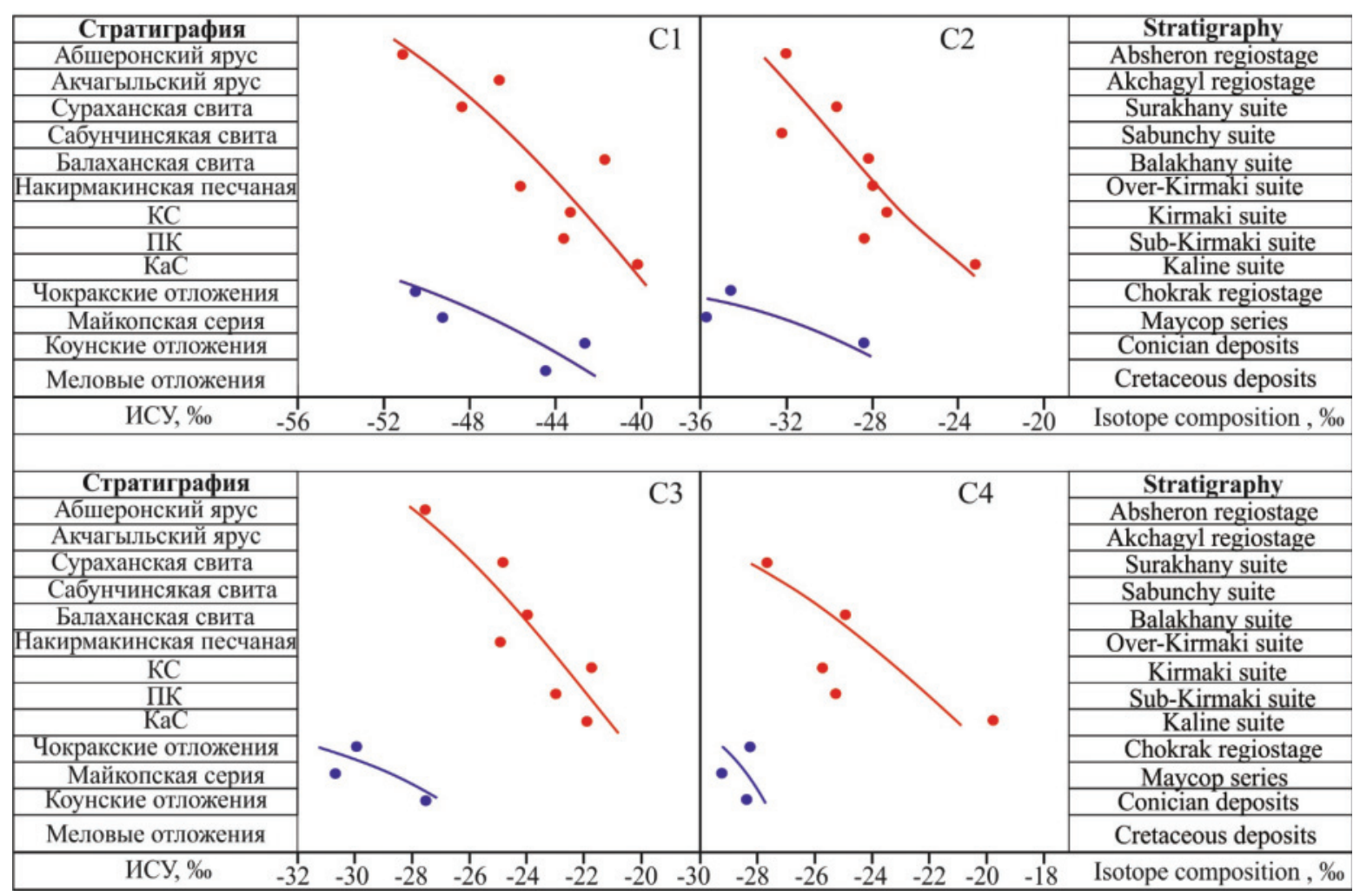

Рис. 8. Изменение изотопного состава УВ газов в зависимости от стратиграфического возраста вмещающих пород

Fig. 8. Change in isotope composition of HC gases, depending on stratigraphic age of enclosing rocks

гиональная площадная дифференциация. В пределах единого стратиграфического горизонта, находящегося на различных гипсометрических уровнях, может наблюдаться разный изотопный состав газов, который отбивает соответствующие интервалы своими характерными чертами. Примером могут служить газы продуктивной толщи, охватывающие широкий диапазон глубин от 2 до 7 км (рис. 9) и более. Анализ изотопного состава углеводородных газов Южно-Каспийской Впадины и установленные закономерности их изменения в зависимости от геологических условий позволили высказать некоторые суждения о генезисе углеводородных газов и накоплении их в известных залежах и выявленных зонах.

Лавинная седиментация, превалирование нисходящих движений над восходящими способствовали накоплению мощных осадков в век продуктивной толщи $[6,8,9]$ и в последующее время. По мере накопления осадков, а также вследствие тектонических процессов (прогибания) в глубоководной части бассейна происходило ужесточение термобарических условий в осадочной толще. С погружением продуктивных комплексов отложений ПТ от бортов $к$ центральной части впадины и по простиранию с северо-запада на юго-восток увеличивалась степень катагенетических преобразований пород. Таким образом, каждый нижележащий стратиграфический интервал погружался и увеличивал степень катагенетической преобразованости. Мощности всех стратиграфических подразде- лений существенно увеличиваются с запада на восток в сторону глубоководной части Каспийского моря, что свидетельствует о возрастании нефтегенерирующей способности осадочной толщи в том же направлении. Районы юго-восточной зоны (глубоководная часть Каспийского моря) относятся к главной зоне нефтеобразования $(Г З Н)$ и соответствуют этапам $\mathrm{MK}_{1}-\mathrm{MK}_{3}$ и палеотемпературам от 90 до $190{ }^{\circ} \mathrm{C}[6,38]$. Это позволяет говорить о том, что в пределах единого стратиграфического горизонта газы могут располагаться в разных фазах формирования. Распределение во времени участков подъема и опускания земной коры в области распространения нефтяных, газоконденсатных и газовых месторождений продуктивной толщи в определенной степени дает возможность судить о направлении миграции углеводородов и масштабах миграции в том или ином направлении. Постоянно сохраняющийся региональный наклон пластов на протяжении длительного геологического времени при постоянном увеличении градиента наклона, имевшем место в век продуктивной толщи и в последующее время в пределах Абшеронского полуострова и архипелага, создавал условия для постоянно установившейся региональной миграции углеводородов в одном, в основном северном, направлении.

Вышеизложенные данные позволяют сделать вывод о том, что региональная миграция углеводородов в пределах Абшеронского нефтегазоносного района происходила из наиболее погруженных 


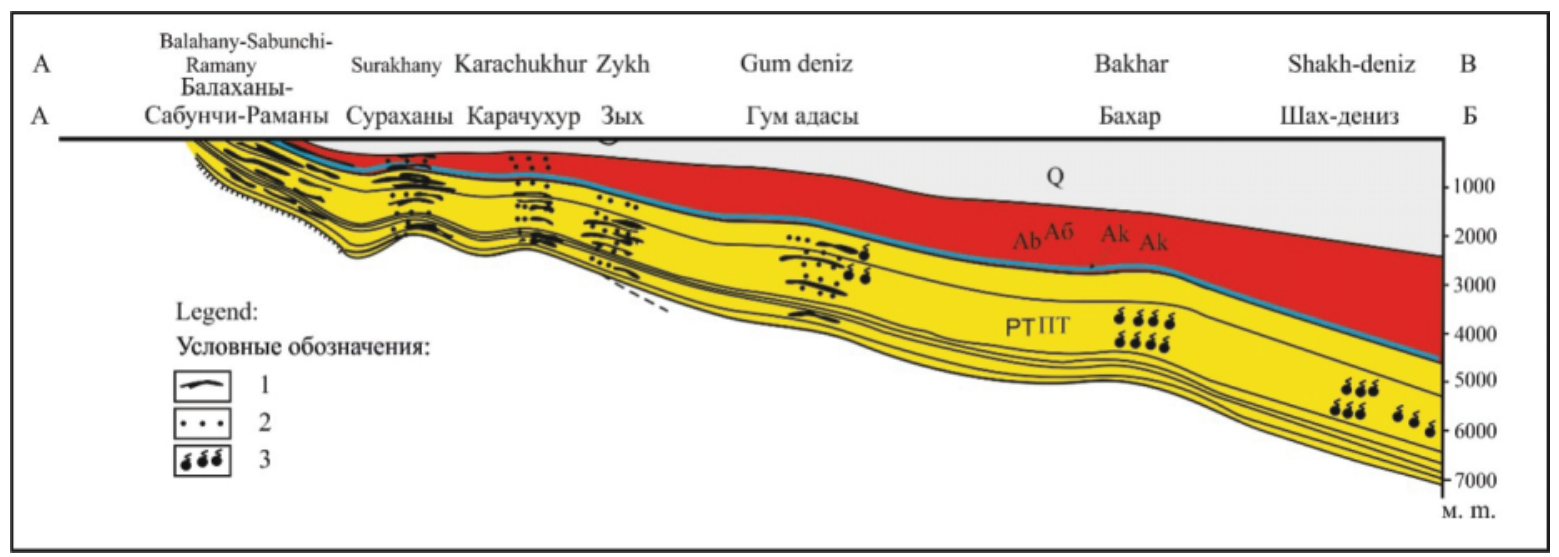

Рис. 9. Нефтегазносность главной антиклинальной зоны Абшеронского полуострова - Кюрдаханы-Шах-дениз. Условные обозначения: 1 - нефтяные залежи с растворенным в нефти газом; 2 - нефтяные залежи с газовыми шапками; 3 - газоконденсатные залежи

Fig. 9. Oil-and-gas content of the main anticlinal zone of Absheron peninsula - Kurdahany-Shakh-deniz. Legend: 1 are the oil deposits with gas dissolved in oil; 2 are the oil deposits with gas caps; 3 are the gas condensate deposits

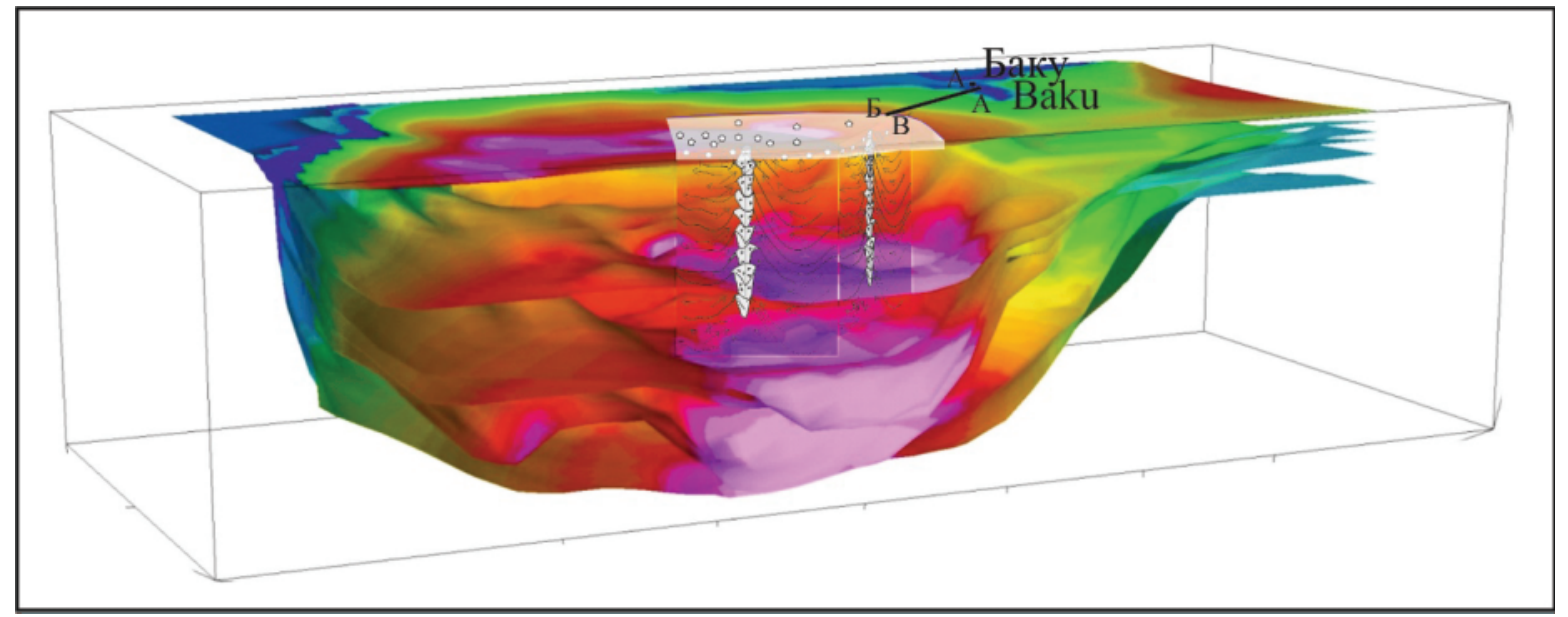

Рис. 10. Модель поступления УВ газов в верхнюю часть разреза в пределах глубоководной части Южного Каспия. Условные обозначения: 1 - подошва плиоцен-четвертичных отложений; 2 - подошва олигоцен-миоценовых отложений; 3 - подошва эоцен-меловых отложений; 4 - подошва юрских отложений

Fig. 10. Model of HC gases entering the upper part of the section within the deep-water part of the South Caspian. Legend: 1 is the bottom of the Pliocene-Quaternary sediments; 2 is the bottom of Oligocene-Miocene deposits; 3 is the bottom of Eocene-Cretaceous deposits; 4 is the bottom of Jurassic deposits

участков Южного Каспия в целом в северном направлении и характеризовалась наибольшей интенсивностью проявления. Кроме этого, поступление углеводородных газов в ВЧР осуществлялась не только благодаря латеральной миграции по пластам, но и вследствие вертикальной миграции по многочисленным грязевым вулканам (рис. 10) и разломам разного порядка и др.

Наряду с тектоническим фактором масштабы миграции определяются и литологическими свойствами пород. Кварцевые песчаники высокой пористости и проницаемости, известные в разрезе продуктивной толщи Абшеронского полуострова и архипелага, а также в нижнем отделе и низах балаханской свиты Бакинского архипелага и в погруженных зонах Южно-Каспийской впадины, служили прекрасными путями для движения как газообразных, так и жидких углеводородов.
В районах Абшеронского нефтегазоносного района значительный и постоянно увеличивающийся региональный наклон пластов сочетается с высокими коллекторскими свойствами песчаных пород и высокой песчанистостью разреза. На основе изложенных представлений образовались гигантские месторождения нефти Балаханы-Сабунчи-Романы и газоконденсата Шах-дениз, расположенные на одной антиклинальной зоне Абшеронского нефтегазоносного района, а также аномалии, выявленные по данным газовой съемки.

\section{Выводы}

В результате исследований построены карты изменения содержания метана, этана, пропана, бутана, изо-, нормального пентана в пределах верхней части разреза по изучаемым месторождениям. Сопоставлены данные результатов анализа газовой 
съемки с данными структурных карт и других геолого-геофизических материалов. Установлено, что структура Бахар характеризуется относительно пониженной интенсивностью газопроявлений по метану от $5,3700 \cdot 10^{-4}$ до $152944 \cdot 10^{-4} \%$ (в среднем $\left.9109,0354 \cdot 10^{-4} \%\right)$, в то время как месторождение Шах-дениз характеризуется максимальными значениями от $4,6200 \cdot 10^{-4}$ до $367840 \cdot 10^{-4} \%$, в среднем составляя $85572,3 \cdot 10^{-4} \%$. Небольшие значения интенсивности газа, установленные в зоне структур Пираллахи, Хали свидетельствуют о незначительном газовом потенциале глубокопогруженных отложений изучаемой зоны. Детально рассмотрены результаты газовой съемки в пределах глубоководной части Южного Каспия и установлено, что для этой зоны характерна газогенерация с преобладанием двух компонентов - метана и этана. Сумма тяжёлых углеводородов установлена только в ряде зон вблизи структур: Д-71, Д-19, Д-15, Д13, Д-12, Д-66, Гюнешли, Чираг и Д-29. Для других зон интенсивность проявления гомологов метана минимальна. Таким образом, можно ожидать, что газогидраты, в составе которых входят гомологи метана, будут установлены в зонах структур: Д-71, Д-19, Д-15, Д-13, Д-12, Д-66 и Д-29. Исходя из анализа изменения интенсивности проявления газа по площади и в зависимости от геологических условий установлено, что грязе-

\section{СПИСОК ЛИТЕРАТУРЫ}

1. Xəzər dənizinin Abşeron arxipelağı və Bakı arxipelağının şimal hissəsində Azərbaycan sektorunda kəsilișin üst hissəsinin qazlılığı və dəniz dibi qaz çıxıșlarının (qaz-hidratlar) öyrənilməsi məqsədilə geoloji-geofiziki və qazma məlumatlarının ümumiləșdirilməsi. - Bakı: ARDNŞ, 2012. - $215 \mathrm{~s}$.

2. Xəzər dənizinin Azərbaycan sektorunda kəsilișin üst hissəsinin qazlılığı və dənizdibi qaz çıxışları: təhlil, ümumiləşdirmə və təkliflər / Y.A. Ş1xəliyev, A.M. Ohmədov, A.Z. Zeynalov, Z.N. Obdiilxakova // Azərbaycan Neft Təsərrüfatı. - 2015. № 5. - S. 9-15.

3. Геологические и геохимические условия сохранения углеводородных флюидов в Южно-Каспийском бассейне. - Баку: Институт Геологии Национальной Академии Наук Азербайджана, 2007. - 175 c.

4. Геология Азербайджана. Нефть и газ / под ред. Ак. А. Али-заде. - Баку: Изд-во «Nafta-Press», 2008. - T. VII. - 380 c.

5. Геология Азербайджана. Гидрогеология и инженерная геология / под ред. Ак. А. Али-заде. - Баку: Изд-во «Nafta-Press», 2008. - T. VIII. $-363 \mathrm{c}$.

6. Гулиев И.С., Дадашев Ф.Г., Полетаев А.В. Изотопы углеводородных газов Азербайджана. - Баку: Изд-во «Nafta-Press», 2013. -107 c.

7. Методология изучения и освоения месторождения Булла-дениз / под ред. Ак. А. Али-заде. - Баку: Национальная Академии Наук Азербайджана, Институт глубинных проблем, 1995. -138 c.

8. Алиев А.И. Условия формирования залежей нефти и газа в Южно-Каспийской впадине // Известия Национальной Академии Наук Азербайджана, науки о Земле. -2004. - № 4. C. $13-24$.

9. South Caspian Basin project. Geological Institute of Azerbaijan National Academy of Sciences (GIA), Azerbaijan research Institu- вые вулканы и разломы являются прекрасными путями для миграции углеводородов и отражают геологическую обстановку, генерационный потенциал погруженных отложений Южного Каспия.

Установлено, что углеводородные газы в донных осадках, а также в отложениях верхней части разреза Южной части Каспийского моря находятся в тесной зависимости от источников формирования УВ, миграции и других процессов, протекающих в глубокопогруженных отложениях, а также в верхней части разреза. С целью изучения генезиса УВ газов ВЧР исследованы данные химического и изотопного состава газов газогидратов Южного Каспия, донных осадков, нефтяных и газовых месторождений. Изменение изотопного состава углеводородных газов в зависимости от стратиграфического возраста вмещающих отложений позволило выделить две фазы формирования УВ в пределах осадочного комплекса, в связи с чем наблюдается региональная площадная дифференциация.

На базе данных изотопно-геохимических исследований описаны механизмы образования гигантских месторождений нефти Балаханы-Сабунчи-Романы и газоконденсата Шах-дениз, расположенных на одной антиклинальной зоне Абшеронского нефтегазоносного района, а также аномалии, выявленные по данным газовой съемки.

te of Geophysics (SOCAR), Earth Sciences and Resources Institute of the South Carolina (ESRI). - 1995. - $171 \mathrm{p}$.

10. Изучение и прогнозирование параметров сложных природных резервуаров нефти и газа Южно-Каспийской впадины / М.Т. Абасов, Ю.М. Кондрушкин, Р.Ю. Алияров, Л.Г. Крутых. - Баку, Изд-во «Nafta-Press», 2007. -217 с.

11. South-Caspian Basin: geology, geophysics, oil and gas content / ed. by A.A. Ali-Zadeh. -Baku, Nafta-Press, 2004. - 333 p.

12. Guliyev I.S., Levin L.E., Fedorov D.L. Hydrocarbons potential of the Caspian region (System Analysis). - Baku: Nafta-Press, 2003. $-120 \mathrm{p}$.

13. Feyzullayev A.A., Huseynov D.A. Hydrocarbon potential and resources of Lower Pliocene-Productive series in South Caspian basin. Stratigraphy and sedimentology of oil-gas basins. - Baku: Nafta-Press, 2016. - № 1. - P. 99-104.

14. Гинсбург Г.Д., Соловьев В.А. Субмаринные газовые гидраты. СПб.: ВНИИОкеангеология, 1994. - 193 с.

15. Гусейнов Р.А., Дадашев Ф.Г. Углеводородные газы Каспийского моря. - Баку: Nafta-Press, 2000. - 128 c.

16. Оценка перспектив нефтегазоносности акваторий Шахово-мо$\mathrm{pe}$ - Булла-море газогеохимическими методами и направление дальнейших поисково-разведочных работ / Ф.Г. Дадашев, Ч.С. Мурадов и др. - Баку: Фонд Института геологии НАН Азербайджана, 1980. - 20 с.

17. Полетаев А.В., Полетаева Е.В. Изученность диаграмм гетерогенного равновесия в координатах давления и температуры: гидратообразования // Перспективы развития научного знания в XXI веке. Экономика России: проблемы, тенденции, перспективы. - Тамбов: ИД ТГУ, 2015. - Вып. 4. - С. 104-111.

18. Полетаев А.В., Полетаева Е.В. История изученности газогидратов Южного Каспия // Перспективы развития научного знания в XXI веке. - 2015. - № 3. - С. 188-193.

19. A Multicomponent Anomaly in the Bottom Sediments and Sea water of the Central Part of the South Caspian Depression / I.S. Gu- 
liev, G.-M.A. Aliev, E.G. Alieva, Ch.S. Muradov // Geochemistry International. - 2000. - V. 38. - № 9. - P. 921-928.

20. Велиев Г., Цурков M. SOCAR огласила объемы прибыльной нефти с АЧГ. URL: www.trend.az/news_print.php?news_id= 2389385 (дата обращения 18.04.2018).

21. Mud volcanoes and structural development on Shah Deniz / S.R. Fowler, J. Mildenhall, S. Zalova, G. Riley, G. Elsley, A. Desplanques, F. Guliyev // Journal of Petroleum Science and Engineering. - 2000. - № 28. - P. 189-206.

22. Агишев А.П. Межпластовые перетоки газа при разработке газовых месторождений. - М.: Недра, 1966. - 204 с.

23. Musakaev N.G., Khasanov M.K., Borodin S.L. The mathematical model of the gas hydrate deposit development in permafrost // International Journal of Heat and Mass Transfer. - 2018. V. 118. - P. 455-461.

24. Şükrü Merey, Sotirios Nik Longinos. Numerical simulations of gas production from Class 1 hydrate and Class 3 hydrate in the Nile Delta of the Mediterranean Sea // Journal of Natural Gas Science and Engineering. - 2018. - V. 52. - P. 248-266.

25. Geophysical characterization of a fine-grained gas hydrate reservoir in the Shenhu area, northern South China Sea: Integration of seismic data and downhole logs / Jiliang Wang, Shiguo Wu, Xiu Kong, Qingping Li, Jianxin Wang, Rong Ding // Marine and Petroleum Geology. - 2018. - V. 92. - P. 895-903.

26. Lorenson Th.D., Collett T.S. National Gas Hydrate Program Expedition 01 offshore India; gas hydrate systems as revealed by hydrocarbon gas geochemistry // Marine and Petroleum Geology. 2018. - V. 92. - P. 477-492.

27. Estimation of seismic velocities and gas hydrate concentrations: a case study from the Shenhu area, northern South China Sea / Jie Liu, Jianzhong Zhang, Fei Ma, Ming Wang, Yunbao Sun // Marine and Petroleum Geology. - 2017. - V. 88. - P. 225-234.

28. High-resolution seismic characterization of the gas and gas hydrate system at Green Canyon 955, Gulf of Mexico, USA / S.S. Haines, P.E. Hart, T.S. Collett, W. Shedd, M. Frye, P. Weimer, R. Boswell // Marine and Petroleum Geology. - 2017. - V. 82. P. $220-237$.

29. Zijian Zhang, Wright Ch.S. Quantitative interpretations and assessments of a fractured gas hydrate reservoir using three-dimensional seismic and LWD data in Kutei basin, East Kalimantan, offshore Indonesia // Marine and Petroleum Geology. - 2017. V. 84. - P. 257-273.
30. Musakaev N.G., Khasanov M.K., Borodin S.L. The mathematical model of the gas hydrate deposit development in permafrost // International Journal of Heat and Mass Transfer. - 2018. V. 118. - P. 455-461.

31. Yarveicy H., Ghiasi M.M., Mohammadi A.H. Determination of the gas hydrate formation limits to isenthalpic Joule-Thomson expansions // Chemical Engineering Research and Design. 2018. - V. 132. - P. 208-214.

32. Differential fluid migration behaviour and tectonic movement in Lower Silurian and Lower Cambrian shale gas systems in China using isotope geochemistry/ Hao Xu, Wen Zhou, Qian Cao, Christopher Xiao, Qiumei Zhou, Haotian Zhang, Yeyu Zhan // Mar. Pet. Geol. - 2017. - V. 89. - P. 47-57.

33. Seismic evidence and formation mechanism of gas hydrates in the Zhongjiannan Basin, Western margin of the South China Sea / Yintao Lu, Xiwu Luan, Fuliang Lyu, Bin Wang, Zhili Yang, Taotao Yang, Genshun Yao // Marine and Petroleum Geology. 2017. - V. 84. - P. 274-288.

34. Genetic types of gas hydrates in China / Jinxing Dai, Yunyan Ni, Shipeng Huang, Weilong Peng, Wenxue Han, Deyu Gong, Wei Wei // Petroleum Exploration and Development. - 2017. V. 44. - P. 887-898.

35. Hydrocarbon source for oil and gas indication associated with gas hydrate and its significance in the Qilian Mountain permafrost, Qinghai, Northwest China / Bin Cheng, Jianbing Xu, Zhenquan $\mathrm{Lu}$, Yonghong Li, Weichao Wang, Shan Yang, Hu Liu, Ting Wang, Zewen Liao // Mar. Pet. Geol. - 2017. - V. 89. P. 202-215.

36. Methane source linked to gas hydrate system at hydrate drilling areas of the South China Sea: orewater geochemistry and numerical model constraints / Yu Hu, Min Luo, Linying Chen, Qianyong Liang, Dong Feng, Jun Tao, Shengxiong Yang, Duofu Chen // Journal of Asian Earth Sciences. - 2018. - V. 44. - P. 2-15.

37. Contribution of thermogenic organic matter to the formation of biogenic gas hydrate: Evidence from geochemical and microbial characteristics of hydrate-containing sediments in the Taixinan Basin, South China Sea / Junli Gong, Xiaoming Sun, Li Xu, Hongfeng Lu // Marine and Petroleum Geology. - 2017. V. 80 . - P. $432-449$.

38. Geothermal Atlas of Azerbaijan / ed. by A.A. Ali-Zadeh, S.A. Aliyev. - Baku, Nafta-Press 2001. - 151 p.

Поступила 18.09.2018 г.

\section{Информация об авторах}

Полетаев A.B., кандидат геолого-минералогических наук, ведущий научный сотрудник Института нефти и газа Национальной Академии Наук Азербайджана.

Полетаева E.B., доктор философии по наукам о Земле, ведущий научный сотрудник Института нефти и газа Национальной Академии Наук Азербайджана. 
UDK $550.4,550.46$

\title{
STUDY OF HYDROCARBON GAS OUTPUTS DISTRIBUTION DEPENDING ON GEOLOGICAL STRUCTURE OF THE SOUTHERN CASPIAN BY GAS SURVEY
}

\author{
Alexander V. Poletayev', \\ avo1@mail.ru \\ Yelena V. Poletayeva', \\ yelenapv@mail.ru \\ 1 National Academy of Sciences of Azerbaijan, \\ 9, F. Amirovstreet, Baku, AZ1000, Azerbaiijan.
}

The relevance of the research is in studying the gases of the Southern Caspian section upper part, in particular its deep-water part, which is of significant practical interest when searching and estimating hydrocarbon potential of gas hydrate zones. The analysis of the works carried out within the South Caspian showed that all the studies are mainly concentrated within the drilled zone of Absheron, Baku and Nizhnyaya Kura oil and gas regions, and do not cover the deep-sea zone of the Southern Caspian.

The aim of the research is to study hydrocarbon gases intensity distribution by area, as well as to determine gas generation zones. In addition, the work was carried out to determine and analyze hydrocarbon migration routes and types of formation of gas hydrates within the deep-sea zone of the Southern Caspian.

The object of the researchwas 1282 gas samples selected in the South Caspian at Shah Deniz, Bakhar, Pirallahi, Khali, deep-water South Caspian, and other geological and geophysical data. The data on chemical and isotope composition of the hydrocarbon gases of the South Caspian basin were used on 147 gas samples taken from oil and gas fields, 153 samples from mud volcanoes, 29 samples from bottom sediments and 4 samples from gas hydrates. These data enabled more reasonable approach to the analysis of genetic issues of gases origin in the upper part of the section.

Research methods are based on interpretation of gas survey data and investigation of isotope and chemical composition of hydrocarbon gases of the Southern Caspian. The presence of exact values of coordinates, as well as data on structural maps in the grid, enabled to compare the available data with the geological structure.

Result. The authors have constructed the maps of the change in the content of methane, ethane, propane, butane, iso-, normal pentane within the upper part of the section for the studied deposits and compared the data of the results of the analysis of gas survey with the data of structural maps and other geological and geophysical material. It is established that the structure of the Bakhar is characterized by a relatively low intensity of methane gas reservoirs from $5,37 \cdot 10^{-4}$ to $152944 \cdot 10^{-4} \%$ (average $9109,0354 \cdot 10^{-4} \%$ ), while the Shah Deniz field is characterized by the maximum values from $4,6200 \cdot 10^{-4}$ to $367,840 \cdot 10^{-4} \%$, an average of $85,572,3 \cdot 10^{-4} \%$. Small values of gas intensity, established in the zone of the structures of Pirallakhi, Khali, indicate insignificant gas potential of deep-seated deposits of the studied zone. The results of the gas survey within the deep-water part of the South Caspian were considered in detail and it was established that for this zone gas generation is typical, with the predominance of two components - methane and ethane. Based on the analysis of the change in the intensity of gas manifestations by area and depending on geological conditions it was established that mud volcanoes and faults are excellent ways for hydrocarbon migration and reflect the geological situation and the generation potential of the submerged deposits of the Southern Caspian. It was established that hydrocarbon gases in bottom sediments and sediments of the upper part of the South Caspian section are closely related to the sources of hydrocarbon formation, migration and other processes occurring in deeply buried sediments, as well as in upper part of the section. The authors studied the data of the chemical and isotopic composition of gas hydratesgases, oil and gas deposits of the South Caspian. Based on the data of isotope-geochemical studies the authors described the mechanisms of formation of giant oil deposits of Balakhany-Sabunchi-Romana and Shahdeniz gas condensate located on one anticlinal zone of the Absheron oil and gas bearing area, as well as anomalies revealed from gas survey data within the studied structures of the South Caspian.

\section{Key words:}

Gas survey, South Caspian, faults, mud volcanoes, gas content.

\section{REFERENCES}

1. Xəzər dənizinin Abșeron arxipelağı və Bakı arxipelağının șimal hissəsindəAzərbaycan sektorunda kəsilişin üst hissəsinin qazlılığ 1 və dəniz dibi qaz çıxıslarının (qaz-hidratlar) öyronilməsi məqsadila geoloji-geofiziki va qazma məlumatlarının ümumiləşdirilməsi [Gas hearing capacity in upper part of section and sea bottom gas shows (gas hydrates) in Absheron archipelago and northern part of Baku archipelago of Azerbaijan sector Caspian Sea with aims geological, geophysical and drilling data collection]. Baku, SOCAR Publ., 2012. 215 p.

2. Ş1xəliyev Y.A., วhmədov A.M., Zeynalov A.Z., วbdiilxakova Z.N. Xəzər dənizinin Azərbaycan sektorunda kəsilişin üst hissəsinin qazlılığı və dənizdibi qaz çıxışları: təhlil, ümumiləşdirmə və təkliflər [Gas hearing capacity in upper portion of section and sea bottom gas shows in Azerbaijan sector of Caspian
Sea: analysis, summary and proposals]. Geologiyavəgeofizika Geology and Geophisics, 2015, no. 5, pp. 9-15.

3. Geologicheskie i geokhimicheskie usloviya sokhraneniya uglevodorodnykh flyuidov v Yuzhno-Kaspiyskom Basseyne [Geological and geochemical conditions for conservation of hydrocarbon fluids in the South Caspian basin]. Baku, Institut Geologii Natsionalnoy Akademii Nauk Azerbaydzhana-SIW, Geology Institute of National Academy of Sciences Azerbaijan, 2007. 175 p.

4. Geologiya Azerbaydzhana. T.VII. Neft i gaz [Geology of Azerbaijan. Vol. VII. Oil and gas]. Ed. by A.A. Ali-Zadeh. Baku, NaftaPress, 2008. $380 \mathrm{p}$.

5. Geologiya Azerbaydzhana. T.VIII. Gidrogeologiya i inzhenernaya geologiya [Hydrogeology and engineering geology. Vol. VIII. Hydrogeology and engineering geology]. Ed. by A.A. Ali-Zadeh. Baku, Nafta-Press, 2008. $363 \mathrm{p}$ 
6. Guliev I.S., Dadashev F.G. Poletaev A.V. Izotopy uglevodorodnykh gazov Azerbaydzhana [Isotopes of hydrocarbon gases of Azerbaijan]. Baku, Nafta-Press, 2013. 107 p.

7. Metodologiya izucheniy i osvoeniya mestorozhdeniya Bulla-Deniz [Methodology of studying and developing the Bulla-Deniz field]. Ed. by A.A. Ali-Zadeh. Baku, National Academy of Sciences of Azerbaijan, the Institute of Deep Problems, 1995. $138 \mathrm{p}$

8. Aliev A.I. Usloviya formirovaniya zalezhey nefti i gaza $v$ YuzhnoKaspiyskoy Vpadine [Oil and gas formation conditions in the South Caspian Depression]. Proceedings of the ANAS, Earth Sciences, 2004, no. 4, pp. 13-24.

9. South Caspian Basin project. Geological Institute of Azerbaijan National Academy of Sciences (GIA), Azerbaijan research Institute of Geophysics (SOCAR), Earth Sciences and Resources Institute of the South Carolina (ESRI), 1995. $171 \mathrm{p}$.

10. Abasov M.T., Kondrushkin Yu.M., Aliyarov R.Yu., Krutykh L.G. Izuchenie i prognozirovanie parametrov slozhnykh prirodnykh rezervuarou nefti i gaza Yuzhno Kaspiyskoy Vpadiny [Investigation and prediction of difficult natural reservoir oil and gas in the South Caspian Sea]. Baku, Nafta-Press, 2007. 217 p.

11. South-Caspian Basin: geology, geophysics, oil and gas content. Ed. by A.A. Ali-Zadeh. Baku, Nafta-Press, 2004. 333 p.

12. Guliyev I.S., Levin L.E., Fedorov D.L. Hydrocarbons potential of the Caspian region (System Analysis). Baku, Nafta-Press, 2003. $120 \mathrm{p}$.

13. Feyzullayev A.A., Huseynov D.A. Hydrocarbon potential and resources of Lower Pliocene-Productive series in South Caspian basin. Stratigraphy and sedimentology of oil-gas basins. Baku, NaftaPress, 2016, no. 1, pp. 99-104.

14. Ginsburg G.D., Solovev V.A. Submarinnye gazovyegidraty [Submarine gas hydrates]. St. Petersburg, VNIIOkeangeologiya Publ., $1994.193 \mathrm{p}$

15. Guseynov R.A., Dadashev F.G. Uglevodorodnye gazy kaspiyskogo morya [Hydrocarbon gases of the Caspian Sea]. Baku, NaftaPress, $2000.128 \mathrm{p}$.

16. Dadashev F.G., Muradov Ch.S. Otsenka perspektiv neftegazonosnosti akvatoriy Shakhovo-More - Bulla-More gazogeokhimicheskimi metodami $i$ napravlenie dalneyshikh poiskovo-razvedochnykh rabot [Assessment of oil and gas content prospective within Shakhov-Sea -Bulla-Sea water areas using gas geochemical methods and the trend of further prospecting works]. Baku, Foundation of Geology Institute of National Academy of Sciences Azerbaijan, 1980.20 p.

17. Poletaev A.V., Poletaeva E.V. Izuchennost diagramm geterogennogo ravnovesiya $\mathrm{v}$ koordinatakh davleniya i temperatury: gidratoobrazovaniya [Study of heterogenous equilibrium in pressure and temperature coordinates: formation of hydrates]. Perspektivy razvitiya nauchnogo znaniya $V X X I$ veke. Ekonomika Rossii: problemy, tendentsii, perspektivy [Perspective of scientific knowledge development in the XXI century. Russian economic: problems, tendentious, perspectives]. Tambov, TSU Publ. house, 2015. Iss. 4, pp. 104-111.

18. Poletaev A.V., Poletaeva E.V. Istoriya izuchennosti gazogidratov Yuzhnogo Kaspiya [History of the study of gas hydrates of South Caspian]. Perspective of scientific knowledge development in the XXI century, 2015, vol. 3, no. 3, pp. 188-193.

19. Guliev I.S., Aliev G.-M.A., Alieva E.G., Muradov Ch.S. A Multicomponent Anomaly in the Bottom Sediments and Seawater of the Central Part of the South Caspian Depression. Geochemistry International, 2000, vol. 38, no. 9, pp. 921-928.

20. Veliev G., Tsurkov M. SOCAR oglasila obemy pribylnoy nefti s $A C h G$ [SOCAR published information about commercial oil volume from AGC fields]. Available at: www.Trend.Az/News Print.Php?News_Id=2389385 (accessed 18 April 2018).

21. Fowler S.R., Mildenhall J., Zalova S., Riley G., Elsley G., Desplanques A., Guliyev F. Mud volcanoes and structural develop- ment on Shah Deniz. Journal of Petroleum Science and Engineering, 2000, vol. 28, pp. 189-206.

22. Agishev A.P. Mezhplastovye peretoki gaza prirazrabotke gazovykh mestorozhdeniy [Interlayer gas migrations in gas while drilling]. Moscow, Nedra Publ., 1966. 204 p.

23. Musakaev N.G., Khasanov M.K., Borodin S.L. The mathematical model of the gas hydrate deposit development in permafrost. International Journal of Heat and Mass Transfer, 2018, vol. 118, pp. $455-461$.

24. Şükrü Merey, Sotirios Nik Longinos. Numerical simulations of gas production from Class 1 hydrate and Class 3 hydrate in the Nile Delta of the Mediterranean Sea. Journal of Natural Gas Science and Engineering, 2018, vol. 52, pp. 248-266.

25. Jiliang Wang, Shiguo Wu, Xiu Kong, Qingping Li, Jianxin Wang, Rong Ding. Geophysical characterization of a fine-grained gas hydrate reservoir in the Shenhu area, northern South China Sea: Integration of seismic data and downhole logs. Marine and Petroleum Geology, 2018, vol. 92, pp. 895-903.

26. Lorenson Th.D., Collett T.S. National Gas Hydrate Program Expedition 01 offshore India; gas hydrate systems as revealed by hydrocarbon gas geochemistry. Marine and Petroleum Geology, 2018, vol. 92, pp. 477-492.

27. Jie Liu, Jianzhong Zhang, Fei Ma, Ming Wang, Yunbao Sun. Estimation of seismic velocities and gas hydrate concentrations: a case study from the Shenhu area, northern South China Sea. $M a$ rine and Petroleum Geology, 2017, vol. 88, pp. 225-234.

28. Haines S.S., Hart P.E., Collett T.S., Shedd W., Frye M., Weimer P., Boswell R. High-resolution seismic characterization of the gas and gas hydrate system at Green Canyon 955, Gulf of Mexico, USA. Marine and Petroleum Geology, 2017, vol. 82, pp. 220-237.

29. Zijian Zhang, Wright Ch.S. Quantitative interpretations and assessments of a fractured gas hydrate reservoir using three-dimensional seismic and LWD data in Kutei basin, East Kalimantan, offshore Indonesia. Marine and Petroleum Geology, 2017, vol. 84, pp. 257-273.

30. Musakaev N.G., Khasanov M.K., Borodin S.L. The mathematical model of the gas hydrate deposit development in permafrost. International Journal of Heat and Mass Transfer, 2018, vol. 118, pp. 455-461.

31. Yarveicy H., Ghiasi M.M., Mohammadi A.H. Determination of the gas hydrate formation limits to isenthalpic Joule-Thomson expansions. Chemical Engineering Research and Design, 2018, vol. 132, pp. 208-214.

32. Hao Xu, Wen Zhou, Qian Cao, Christopher Xiao, Qiumei Zhou, Haotian Zhang, Yeyu Zhan. Differential fluid migration behaviour and tectonic movement in Lower Silurian and Lower Cambrian shale gas systems in China using isotope geochemistry. Mar. Pet. Geol., 2017, vol. 89, pp. 47-57.

33. Yintao Lu, Xiwu Luan, Fuliang Lyu, Bin Wang, Zhili Yang, Taotao Yang, Genshun Yao. Seismic evidence and formation mechanism of gas hydrates in the Zhongjiannan Basin, Western margin of the South China Sea. Marine and Petroleum Geology, 2017, vol. 84, pp. 274-288.

34. Jinxing Dai, Yunyan Ni, Shipeng Huang, Weilong Peng, Wenxue Han, Deyu Gong, Wei Wei. Genetic types of gas hydrates in China. Petroleum Exploration and Development, 2017, vol. 44, pp. 887-898.

35. Bin Cheng, Jianbing $\mathrm{Xu}$, Zhenquan Lu, Yonghong Li, Weichao Wang, Shan Yang, Hu Liu, Ting Wang, Zewen Liao. Hydrocarbon source for oil and gas indication associated with gas hydrate and its significance in the Qilian Mountain permafrost, Qinghai, Northwest China. Mar. Pet. Geol., 2017, vol. 89, pp. 202-215.

36. Yu Hu, Min Luo, Linying Chen, Qianyong Liang, Dong Feng, Jun Tao, Shengxiong Yang, Duofu Chen. Methane source linked to gas hydrate system at hydrate drilling areas of the South China Sea: 
orewater geochemistry and numerical model constraints. Journal of Asian Earth Sciences, 2018, vol. 44, pp. 2-15.

37. Junli Gong, Xiaoming Sun, Li Xu, Hongfeng Lu. Contribution of thermogenic organic matter to the formation of biogenic gas hydrate: Evidence from geochemical and microbial characteristics of hydrate-containing sediments in the Taixinan Basin, South China Sea. Marine and Petroleum Geology, 2017, vol. 80, pp. 432-449.
38. Geothermal Atlas of Azerbaijan. Ed. by A.A. Ali-Zadeh, S.A. Aliyev. Baku, Nafta-Press 2001. 151 p.

Received: 18 September 2018.

\section{Information about the authors}

Alexander V. Poletayev, Cand. Sc., leading researcher, Oil and Gas Institute of National Academy of Sciences of Azerbaijan.

Yelena V. Poletayeva, Dr. Sc., leading researcher, Oil and Gas Institute of National Academy of Sciences of Azerbaijan. 